\title{
The Spleen as an Optimal Site for Islet Transplantation and a Source of Mesenchymal Stem Cells
}

\author{
Naoaki Sakata ${ }^{1}$ (D), Gumpei Yoshimatsu ${ }^{2}$ and Shohta Kodama ${ }^{1,2,3, *}$ \\ 1 Department of Regenerative Medicine and Transplantation, Faculty of Medicine, Fukuoka University, \\ Fukuoka 814-0180, Japan; naoakisakata@fukuoka-u.ac.jp \\ 2 Center for Regenerative Medicine, Fukuoka University Hospital, Fukuoka 814-0180, Japan; \\ gyoshimatsu@fukuoka-u.ac.jp \\ 3 Research Institute for Regenerative Medicine, Fukuoka University, 7-45-1 Nanakuma, Jonan-ku, \\ Fukuoka 814-0180, Japan \\ * Correspondence: skodama@fukuoka-u.ac.jp; Tel.: +81-92-801-1011 (ext. 3631); Fax: +81-92-801-1019
}

Received: 2 April 2018; Accepted: 4 May 2018; Published: 7 May 2018

\begin{abstract}
This review demonstrates the unique potential of the spleen as an optimal site for islet transplantation and as a source of mesenchymal stem cells. Islet transplantation is a cellular replacement therapy used to treat severe diabetes mellitus; however, its clinical outcome is currently unsatisfactory. Selection of the most appropriate transplantation site is a major factor affecting the clinical success of this therapy. The spleen has long been studied as a candidate site for islet transplantation. Its advantages include physiological insulin drainage and regulation of immunity, and it has recently also been shown to contribute to the regeneration of transplanted islets. However, the efficacy of transplantation in the spleen is lower than that of intraportal transplantation, which is the current representative method of clinical islet transplantation. Safer and more effective methods of islet transplantation need to be established to allow the spleen to be used for clinical transplantation. The spleen is also of interest as a mesenchymal stem cell reservoir. Splenic mesenchymal stem cells contribute to the repair of damaged tissue, and their infusion may thus be a promising therapy for autoimmune diseases, including type 1 diabetes mellitus and Sjogren's syndrome.
\end{abstract}

Keywords: spleen; islet transplantation; transplant site; immunity; tolerance; regeneration; diabetes mellitus; mesenchymal stem cell; Sjogren's syndrome; HOX

\section{Introduction}

The spleen is located in the left upper quadrant of the abdomen. It is a peripheral lymphoid organ with an important role in the immune system, including in the maturation of B cells, T cells and plasma cells, and the production of immunoglobulin M [1]. The spleen also acts as a hematopoietic organ during the prenatal period and in the event of massive hemorrhage and bone marrow deficiency, and acts to remove old red blood cells and as a blood reserve. Nevertheless, the spleen has frequently been considered as an "unnecessary organ" because its functions can also be carried out by other organs, and loss of the spleen does not directly lead to death. Splenectomy has therefore been widely performed in patients with splenic injuries or pancreatic malignant tumors. However, overwhelming postsplenectomy infection has recently been recognized as a severe complication of splenectomy, associated with high mortality. Furthermore, loss of the spleen causes immunological hypofunction, leading to exacerbation of bacterial infections involving Streptococcus pneumoniae, Haemophilus influenzae and Neisseria meningitides [2], thus emphasizing the importance of this organ. 
The importance of the spleen is not limited to its immunological properties [3]. In this review, we demonstrate the unique potential of the spleen as an optimal site for islet transplantation and as a source of mesenchymal stem cells.

\section{Islet Transplantation and Its Obstacles}

Islet transplantation is a cellular replacement therapy used to treat severe diabetes mellitus in patients who are unable to control their blood glucose levels, even with intensive insulin treatment. Islet transplantation enables patients to receive an appropriate supply of insulin in response to changes in blood glucose levels, and can help to prevent severe hypoglycemia and life-threatening complications, including cardiomyopathy, nephropathy, retinopathy and neuropathy [4-6]. Islet transplantation was first established in the clinic in the 1970s [7], but early therapeutic outcomes were inadequate, and islet transplantation is still regarded as an experimental therapy. At the end of the 1990 s, fewer than $50 \%$ of patients achieved insulin-independence two months after islet transplantation and fewer than 10\% after a year [8]. However, the development of an automated method of islet isolation in the mid-1980s represented a turning point in islet transplantation. This method involves the progressive chemical and mechanical digestion of the pancreas in warm collagenase solution using a digestion chamber known as a Ricordi chamber [9]. The islets are then purified from the digested pancreatic tissue by density-gradient separation using a blood cell processor (IBM 2991 device, sold as COBE $2991^{\circledR}$; Terumo BCT, Inc., Lakewood, CO, USA). These advances in digestion and islet purification techniques have enabled large numbers of islets to be harvested with high purity, and contributed to the first clinically successful islet transplantation at Washington University in St Louis in 1989. This was performed in a 36-year-old woman with type 1 diabetes mellitus, who received transplantation of approximately 800,000 islet equivalents and who subsequently achieved normoglycemia for 22 days without insulin treatment [10].

Another turning point was the development of an effective immunosuppressive regimen for islet transplantation. In 1990, a group in Pittsburg successfully prolonged insulin independence for over three months in a clinical allogeneic islet transplantation study using tacrolimus (FK506) [11]. Tacrolimus is a calcineurin inhibitor that is required for T-cell receptor induction of interleukin-2 (IL-2) and for T cell proliferation. It has a superior safety profile compared with the earlier calcineurin inhibitor, cyclosporine [12,13]. At the end of 1990s, an Edmonton group developed an islet transplantation protocol using the steroid-free immunosuppressive agents sirolimus, daclizumab and tacrolimus, and reported on seven patients with severe type 1 diabetes who were all able to function without insulin treatment with no episodes of hypoglycemic coma [14]. Sirolimus (rapamycin) inhibits the activation of $\mathrm{T}$ and $\mathrm{B}$ cells by suppressing the multifunctional serine-threonine kinase, mammalian target of rapamycin, which is required for efficient production of IL-2 [15,16]. Daclizumab is a monoclonal antibody directed against CD25, a component of the IL-2 receptor, which blocks the formation of the high-affinity IL-2 receptor and can prevent acute rejection by inhibiting the expansion of cytotoxic T cells [17]. The currently recommended protocol includes antithymocyte globulin plus the recombinant soluble tumor necrosis factor receptor protein, etanercept, as induction immunosuppressant agents, followed by tacrolimus or cyclosporine plus mycophenolate mofetil (an inhibitor of purine biosynthesis) for immunosuppression maintenance. A group from Minnesota tested this protocol in six recipients and showed that four of them became insulin-independent for a mean of three years [18].

Novel immunosuppressant regimens are being developed with dramatic speed. In a recent study, human glioblastoma was successfully engrafted for two months in mice administered four treatments of cytotoxic T-lymphocyte-associated protein 4 immunoglobulin and anti-CD154 antibody [19], which induced the immune tolerance required to achieve long-term xenotransplantation. Although this was not an islet transplantation study, it nevertheless demonstrated that it was possible to achieve xenotransplantation, including islet transplantation, by further improvement of immunosuppressants.

The outcome of clinical islet transplantation has improved dramatically over the past 50 years due to technological improvements. A report in 2005 by the Edmonton group, analyzing the long-term 
outcomes of their 65 patients, showed that approximately $80 \%$ of them achieved successful islet engraftment at five years after transplantation (i.e., detection of serum C-peptide and reactivity to glucose stimulation), although only $10 \%$ remained free from insulin treatment [20]. A recent report from the Collaborative Islet Transplant Registry (a registry of clinical islet transplant cases performed in USA, Europe or Australia) indicated that rates of insulin-independence at three years after transplantation have been improving, from $27 \%$ in $1999-2002$ to $44 \%$ in 2007-2010. Positive fasting C-peptide levels $(\geq 0.3 \mathrm{ng} / \mathrm{mL}$ ) were also significantly higher in the period 2007-2010 compared with from 1999-2002 ( $90 \%$ vs. $60 \%$ at three years after transplantation) [21]. Moreover, approximately $80 \%$ of recipients who received $\geq 600,000$ total islet equivalents achieved insulin independence, compared with $55 \%$ who received $<600,000$ islet equivalents [22]. Islet transplantation is therefore now considered to be a practical option for treating patients with severe diabetes mellitus to improve endocrine function and prevent hypoglycemic attack; however, clinical outcomes currently remain unsatisfactory. Key requirements for a positive outcome include the acquisition of large numbers of islets from the donor pancreas, prevention of graft loss in the early stage of transplantation and maintaining engraftment for a long period. The transplant site is also an important factor influencing engraftment, and the outcome of clinical islet transplantation could be further improved by utilizing a more suitable transplant site.

\section{Candidate Transplantation Sites for Islets}

The optimal islet transplantation site should meet the following criteria: (1) an abundant, oxygen- and nutrient-rich blood flow; (2) be privileged immunologically to minimize transplant graft loss; and (3) allow transplantation with minimal invasiveness. Numerous organs have been assessed to date, including the liver [23-25], renal subcapsular space [23,24], omental pouch [26,27], mesentery [28], gastrointestinal tract [29], skeletal muscle [30], subcutaneous tissue [30], eye [31], brain [32], testis [33,34], bone marrow [35], thymus [36], and spleen [37]. However, it has been difficult to find a site that meets all three criteria (Table 1$)$.

Table 1. Candidate islet transplantation sites other than the spleen.

\begin{tabular}{|c|c|c|}
\hline Transplant Site & Advantages & Disadvantages \\
\hline Liver & $\begin{array}{ll}\sqrt{ } \quad & \begin{array}{l}\text { Representative site for } \\
\text { clinical transplantation }\end{array} \\
\sqrt{ } & \text { Relatively easy to access } \\
\sqrt{ } & \text { Physiological insulin secretion }\end{array}$ & $\begin{array}{ll}\sqrt{ } & \text { Instant blood-mediated } \\
\sqrt{ } & \text { inflammatory reaction } \\
\sqrt{ } & \text { Innate immunity } \\
\sqrt{ } & \text { Portal thrombosis and hypertension }\end{array}$ \\
\hline Kidney & $\begin{array}{ll}\sqrt{ } \quad \begin{array}{l}\text { Highest transplant efficacy in } \\
\text { rodent models }\end{array} & \end{array}$ & $\begin{array}{l}\sqrt{ } \quad \begin{array}{l}\text { Difficult transplantation due to tight } \\
\text { capsule in large animals }\end{array} \\
\sqrt{ } \quad \begin{array}{l}\text { Systemic insulin release }\end{array}\end{array}$ \\
\hline Omental pouch & $\begin{array}{ll}\sqrt{ } & \begin{array}{l}\text { Potential to accommodate large } \\
\text { numbers of islets }\end{array} \\
\sqrt{ } & \text { Rich vascularity } \\
\sqrt{ } & \text { Physiological insulin secretion }\end{array}$ & $\begin{array}{ll}\sqrt{ } & \text { No reports } \\
\sqrt{ } & \text { No clinical trials } \\
\sqrt{ } & \text { Possibility of risk associated with } \\
& \text { surgery including adhesion and ileus }\end{array}$ \\
\hline Mesentery & $\begin{array}{ll}\sqrt{ } & \text { Rich vascularity } \\
\sqrt{ } & \text { Physiological insulin drainage }\end{array}$ & $\begin{array}{l}\sqrt{ } \quad \begin{array}{l}\text { Impossibility of graft removal without } \\
\text { sacrificing intestinal tract }\end{array}\end{array}$ \\
\hline Gastrointestinal tract & $\begin{array}{ll}\sqrt{ } & \text { Rich vascularity } \\
\sqrt{ } & \text { Physiological insulin secretion } \\
\sqrt{ } & \text { Possibility of endoscopic approach }\end{array}$ & $\begin{array}{l}\sqrt{ } \quad \begin{array}{l}\text { Impossibility of graft removal without } \\
\text { sacrificing intestinal tract }\end{array}\end{array}$ \\
\hline $\begin{array}{l}\text { Muscle and subcutaneous } \\
\text { tissue }\end{array}$ & $\begin{array}{ll}\sqrt{ } \quad & \text { Easiest access with } \\
\text { minimum invasion }\end{array}$ & $\begin{array}{ll}\sqrt{ } & \text { Poorest transplant efficacy } \\
\sqrt{ } & \text { Systemic insulin release }\end{array}$ \\
\hline $\begin{array}{l}\text { Immune privilege site } \\
\text { (brain, testis, eye, thymus) }\end{array}$ & $\begin{array}{ll}\sqrt{ } \quad \begin{array}{l}\text { Prevention, reduction or } \\
\text { suppression of immunity }\end{array}\end{array}$ & $\sqrt{ } \quad$ Difficult clinical setting \\
\hline
\end{tabular}


The liver has long been used as a site for clinical islet transplantation. It is the largest organ and can thus accommodate large numbers of islets following a simple transplant procedure (percutaneous infusion into intrahepatic portal vein using ultrasonography under local anesthesia) [38]. However, transplantation into the liver is also associated with some problems. Many islets are destroyed in the early stages of transplantation, partly due to hypoxia caused by ischemia. The isolated islets are in an avascular state throughout the process of preparation [39] and are exposed to hypoxia in the hypo-oxygenized portal venous blood (mean $\mathrm{PO}_{2}$ approximately $5 \mathrm{mmHg}$ [40]) until revascularization occurs. Moreover, the islets themselves can cause liver ischemia by embolizing the peripheral portal vein $[41,42]$. Inflammation and immunity may also be issues. The transplanted islets are frequently the subject of an innate immune response and are attacked by tissue macrophages in the liver known as Kupffer cells [43,44], and by natural killer cells [45], which may in turn induce an adaptive immune response. Furthermore, infusion of islets into the blood stream can trigger an instant blood-mediated inflammatory reaction (IBMIR), which can damage intraportal transplanted islets [46]. The IBMIR is triggered by the exposure of islet surface molecules, such as tissue factor (coagulation factor III), during islet isolation and purification $[47,48]$. Tissue factor causes rapid binding of platelets, leading to coagulation and complement system activation. Most of the islets are destroyed by this reaction within $1 \mathrm{~h}$ after transplantation [47]. Moreover, some immunosuppressants can be more toxic to islets in the liver because they are present in higher concentrations in the portal vein than in peripheral vessels [49]. Other complications of intraportal islet transplantation include portal hypertension and portal thrombosis. Portal hypertension can increase the risk of post-transplant bleeding, portal thrombosis and sepsis [50,51], while portal thrombosis is a life-threatening complication of islet transplantation, potentially leading to esophageal varices, splenomegaly, mesenteric ischemia, sepsis and death [52].

The kidney (i.e., renal subcapsular space) has frequently been used for islet transplantation in experimental studies, especially in rodents, and islet transplantation into the kidney has been reported to restore normoglycemia. However, these studies used relatively small numbers of islets because the inelastic and tight nature of the human renal subcapsular space makes it is difficult to transplant large numbers of islets [53]. This may explain why clinical progress in renal subcapsular islet transplantation has lagged behind other techniques [54].

Muscle and subcutaneous tissues have also been examined as candidate transplantation sites, given that the transplantation procedure and biopsies can be performed easily with minimal invasion and few complications. However, these sites suffer from hypovascularity and hypoxia, and the transplantation efficacy, especially in subcutaneous tissue, could be improved if these obstacles were overcome [30]. These sites also have the disadvantage of systemic insulin release. In general, secreted insulin from the pancreas flows into the liver via the portal vein, and smaller amounts of insulin are therefore needed to control blood glucose. This is referred to as physiological insulin secretion, compared with systemic insulin release. Islet transplantation into intramuscular and subcutaneous sites results in systemic insulin release, which requires the release of much larger amounts of insulin, similar to those required by insulin injection therapy, because the insulin does not enter the portal system directly.

Another favorable islet transplantation site is the omental pouch. This site has the advantages that its insulin drainage occurs via the portal vein, making it closer to the physiological situation, and the site is highly vascularized [55]. There has been much progress in intra-omental pouch islet transplantation in rodent [27], dog [56] and nonhuman primate models [57]. Because the omental pouch is highly vascularized, it has been proposed as an alternative site for encapsulated islet transplantation [58-60], but no clinical trials have been performed to date.

The mesentery is also considered as a candidate islet transplant site due to its rich vascularization and ability to accommodate many islets. However, it has the disadvantage that, in the event of any problem with the graft, it would be difficult to remove it without damaging the intestinal tract [61]. The submucosal space of the gastrointestinal tract is also a possible transplant site, with a rich vascular 
supply providing oxygen and nutrients, and which connects to the same portal system as the liver, spleen and pancreas [55]. Although Hara and colleagues studied transplantation into this location by endoscopy in a pig model $[29,62]$, there have been limited demonstrations of this concept in large animal models.

The brain, testis, anterior chamber of the eye and thymus are organs where the immunological response is suppressed and are thus considered as "immune privileged" sites. This immune privilege was once assumed to be due to a lack of cellular infiltration and lymphatic drainage [63], but it has recently been shown that it is provided by a complex of immune responses [64]. For example, the brain, testis and retina-blood barrier are maintained in an immunosuppressed condition due to a cellular physical shield [64-66], while regulatory T cells (Tregs) also contribute to immune privilege in some cases. Larocque and colleagues showed that the immune response in the brain could be activated normally when CD4+CD25+ Tregs were depleted [67], while Hedger further revealed that rodent testes contained significant numbers of immunoregulatory cells, including Tregs [68]. Farooq et al. recently showed that Tregs contributed to immune tolerance in the anterior chamber in rodents when challenged by myelin antigen [69]. Many experimental trials have investigated alloand xenogeneic islet transplantation into immune privileged sites in non-human animals. However, although such studies have demonstrated the effectiveness of transplantation into immune privileged sites [31,32,34,36], little has been done in a human clinical setting, and the brain or eye are considered particularly problematic sites for transplantation, because it would be difficult to remove a graft in the event of graft failure without damaging the transplanted organ.

\section{Characteristics of the Spleen as an Islet Transplant Site}

Among the above candidate islet transplant sites, the spleen may represent the optimal site. It is a highly vascularized organ that receives blood from the splenic artery and drains into the portal venous system. Given that vascularization is the most important factor determining the success of transplantation, the spleen provides a rich oxygen and nutrient supply. Furthermore, islets transplanted into the spleen can achieve physiological levels of insulin secretion, given that insulin produced by pancreatic $\beta$ cells flows into the portal-splenic vein (portal venous circulation) [70]. In contrast, insulin provided by a subcutaneous pump or by injection is delivered directly into the systemic circulation. Although recent advances in these insulin injection systems enable them to achieve close to physiological insulin release profiles (i.e., in the portal system), they remain limited by day-to-day changes in insulin sensitivity [71]. Because the spleen connects to the portal venous system, like the liver and pancreas, insulin released from islets transplanted in the spleen flows into the splenic vein.

The spleen is responsible for immune tolerance and thus tends to be immunosuppressed, though to a lesser extent than immune privileged sites such as the testis and thymus. Previous studies have revealed that the spleen is involved in the suppression of $\mathrm{T}$ cell proliferation and antibody production following the induction of immune tolerance [72,73], while other studies have shown that splenic dendritic cells are a good source of suppressor cytokines, including transforming growth factor- $\beta$. The splenic $\mathrm{T}$ cell population was shown to include suppressor $\mathrm{T}$ cells [74], also known as Tregs [75]. Tregs in the spleen prevent antigen presentation by dendritic cells to effector $\mathrm{T}$ cells, and suppress proliferation of effector $\mathrm{T}$ cells via production of suppressor cytokines including transforming growth factor- $\beta$, IL-10 and IL-35 [76]. Horton and colleagues performed intrasplenic allo-transplantation of islets into lymphoid-irradiated dogs that had received donor bone marrow transplantation before transplantation. They observed that islet graft function was maintained after total pancreatectomy without the use of immunosuppressants [77]. Moreover, splenocytes themselves may help regulate autoimmunity. We previously rescued non-obese (NOD) mice (representative type 1 diabetes mellitus animal model) from a severe diabetic condition by injection of live donor splenocytes with complete Freund's adjuvant to eliminate autoimmunity. In contrast, NOD mice that received irradiated splenocytes all became diabetic. Immune attack against lymphoid cells was minimal when live splenocytes were injected into complete Freund's adjuvant-infused mice [78,79]. It is therefore not 
surprising that the spleen can also protect transplanted islets from innate inflammatory responses, which are a major factor contributing to islet graft failure, together with acquired immune responses. We previously reported that several kinds of inflammatory cytokines, including monocyte chemotactic protein-1, granulocyte-colony stimulating factor, and high-mobility group box 1 (HMGB1), were increased in the plasma after intraportal islet transplantation [80-82]. We also confirmed that levels of these cytokines were significantly lower in intrasplenic compared with intraportal transplantation [83].

Interestingly, the spleen has been shown to be a reservoir of islet stem cells in diabetic mice (see below). We confirmed that CD45- (nonlymphoid) splenocytes could develop into stem cells and further differentiate into islet progenitor cells, thus contributing to islet regeneration [78]. Moreover, we found that adult mice spleens contained putative mesenchymal stem cells expressing Hox11 (Tlx1, a marker of splenic stem cell [84]) but not Pdx1 (an early pancreatic regeneration marker), which were CD45- in origin [85]. Lee and colleagues provided additional evidence showing that removal of the spleen in children with severe thalassemia led to the eventual development of insulin-dependent diabetes [86]. The spleen may thus facilitate the proliferation of intrasplenic transplanted islets. In 1989, Wohlrab and colleagues first observed the proliferation of $\beta$ cells in intrasplenic transplanted islets at 200 days post-transplantation. They speculated that the proliferative response resulted from long-term stimulation by slightly enhanced plasma glucose levels at the transplantation site [87]. We also observed proliferation of intrasplenic islets transplanted into the renal subcapsule, and these transplanted islets expressed both insulin and ribonucleoside-diphosphate reductase subunit M2 b (Rrm2b) [83]. The Rrm2b gene encodes the small subunit of a p53-inducible ribonucleotide reductase and plays a role in DNA synthesis, and its expression may therefore contribute to proliferation of the transplanted islets [88].

In summary, the spleen may be close to being an optimal site for islet transplantation because of its rich vascularity, physiological insulin secretion, regulation of immunity including autoimmunity and its potential for islet regeneration (Figure 1).
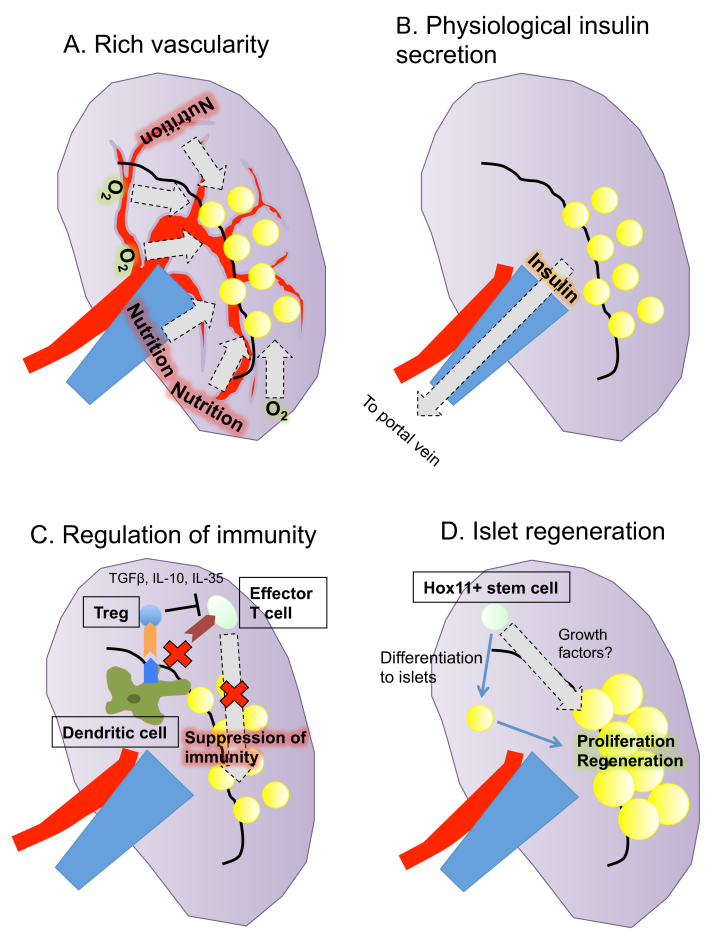

Figure 1. Summary of the characteristics of the spleen as a transplantation site for islets. The spleen has four advantages as a site of islet transplantation: (A) rich vascularity; (B) physiological insulin secretion; (C) regulation of immunity; and (D) potential for islet regeneration. 


\section{Outcomes of Intrasplenic Islet Transplantation}

The major studies on intrasplenic islet transplantation are summarized in Table 2. Historically, intrasplenic islet transplantation has been performed since the late 1970s, when several trials of intrasplenic islet autotransplantation into pancreatectomized dogs demonstrated recovery of endocrine function [89-92]. This model has been used to assess transplantation efficacy [89,90,92-102], and also to assess the transplantation of cold-preserved or cryopreserved islets [103-106] and the toxicity of immunosuppressants [95,107-110]. Other animals, including pigs [111] and monkeys [112-114], have also been used for islet autotransplantation and have shown acceptable outcomes.

Some groups in the 1980s used allo- [115] and xenogeneic [116] islet transplant models. Du Toit and colleagues performed intrasplenic allogeneic islet transplantation in pancreatectomized dogs treated with cyclosporine, and showed that survival was extended in comparison with non-immunosuppressed dogs [115]. Moreover, the usefulness of rapamycin in transplantation was also demonstrated in an allogeneic transplant dog model [117]. Andersson reported the survival of allogeneic grafts from cultured islets for several weeks without the use of any immunosuppressants [118]. In a xenograft model, the Washington group succeeded in prolonging graft survival for more than 100 days using cultured islets in a rat-to-mouse transplant model in which the recipients were treated with anti-rat and/or anti-mouse lymphocyte sera [116]. These findings demonstrated the possibility of using the spleen for the transplantation of allo- and xenogeneic islets.

Table 2. Outcomes of intrasplenic islet transplantation.

\begin{tabular}{|c|c|c|c|}
\hline $\begin{array}{l}\text { Authors } \\
\text { [Reference] }\end{array}$ & $\begin{array}{l}\text { Publication } \\
\text { Year }\end{array}$ & Transplant Model & Comments \\
\hline Kolb E et al. [89] & 1977 & Auto (dog) & $\begin{array}{ll}\sqrt{ } \quad \begin{array}{l}\text { Achieved normoglycemia, but } \\
\text { glucose tolerance was impaired }\end{array}\end{array}$ \\
\hline $\begin{array}{l}\text { Feldman SD et al. } \\
\text { [90] }\end{array}$ & 1977 & Auto (dog) & $\begin{array}{ll}\sqrt{ } \quad & \begin{array}{l}\text { Achieved normoglycemia, but } \\
\text { glucose tolerance was impaired }\end{array} \\
\sqrt{ } & \text { Implantation into splenic pulp }\end{array}$ \\
\hline Gray BN et al. [92] & 1979 & Auto (dog) & $\begin{array}{ll}\sqrt{ } \quad \begin{array}{l}\text { Response of insulin and glucagon to } \\
\text { arginine stimulation }\end{array} \\
\sqrt{ } \quad \text { Implantation into splenic pulp }\end{array}$ \\
\hline $\begin{array}{l}\text { Mehigan DG et al. } \\
\text { [119] }\end{array}$ & 1981 & Auto (dog) & Assessment of quality of collagenase \\
\hline $\begin{array}{l}\text { Andersson A et al. } \\
{[120]}\end{array}$ & 1981 & Iso (mouse) & $\begin{array}{ll}\sqrt{ } \quad \begin{array}{l}\text { Achieved normoglycemia after } \\
\text { transplantation of } 500 \text { islets }\end{array}\end{array}$ \\
\hline $\begin{array}{l}\text { Steffes MW et al. } \\
\text { [121] }\end{array}$ & 1981 & Iso, allo (mouse) & $\begin{array}{l}\sqrt{ } \quad \begin{array}{l}\text { Minimum of } 13 \text { weeks of nearly } \\
\text { normal glucose levels after receiving } \\
\text { skin grafts and spleen cells }\end{array}\end{array}$ \\
\hline $\begin{array}{l}\text { Du Toit DF et al. } \\
\text { [115] }\end{array}$ & 1982 & Allo (dog) & $\begin{array}{ll}\sqrt{ } \quad & \text { Extended survival, but } \\
& \text { normoglycemia not achieved }\end{array}$ \\
\hline $\begin{array}{l}\text { Janney CG et al. } \\
\text { [116] }\end{array}$ & 1982 & $\begin{array}{l}\text { Xeno } \\
\text { (rat-to-mouse) }\end{array}$ & 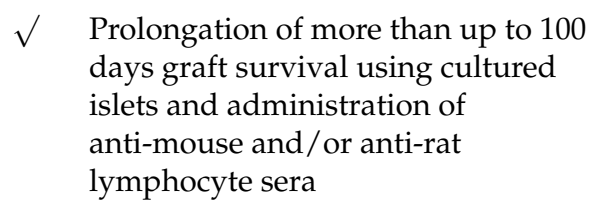 \\
\hline
\end{tabular}


Table 2. Cont.

\begin{tabular}{|c|c|c|c|}
\hline $\begin{array}{l}\text { Authors } \\
\text { [Reference] }\end{array}$ & $\begin{array}{l}\text { Publication } \\
\text { Year }\end{array}$ & Transplant Model & Comments \\
\hline Andersson A. [118] & 1982 & Allo (mouse) & $\begin{array}{l}\sqrt{ } \quad \begin{array}{l}\text { Graft survival of several weeks with } \\
\text { cultured islets but }\end{array} \\
\text { without immunosuppressants }\end{array}$ \\
\hline $\begin{array}{l}\text { Toledo-Pereyra LH } \\
\text { et al. [103] }\end{array}$ & 1983 & Allo (dog) & $\begin{array}{ll}\sqrt{ } \quad \text { Graft using cryopreserved islets was } \\
\text { not rejected for more than } 60 \text { days }\end{array}$ \\
\hline $\begin{array}{l}\text { Warnock GL et al. } \\
\text { [122] }\end{array}$ & 1983 & Iso (dog) & $\begin{array}{ll}\sqrt{ } & \text { Five-month graft survival } \\
\sqrt{ } & \text { Implantation via splenic vein }\end{array}$ \\
\hline Andersson A [123] & 1983 & Iso (mouse) & $\begin{array}{ll}\sqrt{ } \quad \text { Implantation of } 500 \text { islets was } \\
\text { sufficient to achieve normoglycemia, } \\
\text { while implantation of } 150 \text { islets } \\
\text { was not }\end{array}$ \\
\hline $\begin{array}{l}\text { Merrell RC et al. } \\
{[93,94]}\end{array}$ & 1985 & Auto (dog) & $\begin{array}{ll}\sqrt{ } & \text { Achieved normoglycemia } \\
\sqrt{ } & \text { Implantation via splenic vein }\end{array}$ \\
\hline $\begin{array}{l}\text { Kneteman NM et al. } \\
\text { [124] }\end{array}$ & 1985 & Allo (dog) & $\begin{array}{ll}\sqrt{ } \quad \begin{array}{l}\text { Prolongation of graft survival } \\
\text { (approximately 20 days) }\end{array} \\
\text { using cyclosporine }\end{array}$ \\
\hline $\begin{array}{l}\text { Gray DW et al. } \\
{[113]}\end{array}$ & 1986 & Auto (monkey) & $\begin{array}{ll}\sqrt{ } \quad \begin{array}{l}\text { Achieved normoglycemia for } \\
6 \text { months }\end{array} \\
\sqrt{ } \quad \text { First report of monkey model }\end{array}$ \\
\hline Gores PF et al. [95] & 1987 & Auto (dog) & $\begin{array}{l}\sqrt{ } \quad \text { Achieved normoglycemia for more } \\
\text { than } 30 \text { days }\end{array}$ \\
\hline $\begin{array}{l}\text { Kneteman NM et al. } \\
\text { [109] }\end{array}$ & 1987 & Allo (dog) & $\begin{array}{l}\sqrt{ } \quad \begin{array}{l}\text { Achieved normoglycemia for more } \\
\text { than } 100 \text { days using cyclosporine }\end{array} \\
\end{array}$ \\
\hline Hayek A et al. [125] & 1988 & Iso (rat) & $\begin{aligned} & \sqrt{ } \text { Partially achieved normoglycemia by } \\
& \text { transplantation of } 1000 \text { neonatal islets }\end{aligned}$ \\
\hline Sutton R et al. [114] & 1989 & Auto (monkey) & $\begin{array}{l}\sqrt{ } \quad \begin{array}{l}\text { Achieved normoglycemia with } \\
\text { reduced insulin response }\end{array} \\
\text {. }\end{array}$ \\
\hline $\begin{array}{l}\text { Evans MG et al. } \\
\text { [96] }\end{array}$ & 1989 & Auto (dog) & $\begin{array}{l}\sqrt{ } \quad \begin{array}{l}\text { The normoglycemic rate was } 90 \% \text { at } 1 \\
\text { month after transplantation }\end{array}\end{array}$ \\
\hline $\begin{array}{l}\text { van der Vliet JA } \\
\text { et al. }[97,98]\end{array}$ & 1989 & Auto (dog) & Normoglycemic rate $63 \%$ \\
\hline $\begin{array}{l}\text { Warnock GL et al. } \\
\text { [99] }\end{array}$ & 1990 & Auto (dog) & $\begin{array}{ll}\sqrt{ } \quad & \text { Normoglycemic rate } 63 \% \\
\sqrt{ } \quad & \text { Comparison between splenic vein and } \\
& \text { pulp as the route of transplantation. } \\
& \text { Intravenous route superior } \\
& \text { (normoglycemia rate } 86 \% \text { vs. } 33 \% \text { ) }\end{array}$ \\
\hline
\end{tabular}


Table 2. Cont.

\begin{tabular}{|c|c|c|c|}
\hline $\begin{array}{l}\text { Authors } \\
\text { [Reference] }\end{array}$ & $\begin{array}{l}\text { Publication } \\
\text { Year }\end{array}$ & Transplant Model & Comments \\
\hline $\begin{array}{l}\text { Ziegler B et al. } \\
{[126]}\end{array}$ & 1990 & Iso (rat) & $\begin{array}{ll}\sqrt{ } \quad \text { Achieved normoglycemia by } \\
\text { transplantation of } 1,200 \text { islets }\end{array}$ \\
\hline $\begin{array}{l}\text { Korsgren } \mathrm{O} \text { et al. } \\
{[127]}\end{array}$ & 1990 & Iso (mouse) & $\begin{array}{ll}\sqrt{ } \quad & \text { Achieved normoglycemia by } \\
\text { transplantation of } 500 \text { islets }\end{array}$ \\
\hline $\begin{array}{l}\text { Scharp DW et al. } \\
\text { [100] }\end{array}$ & 1992 & Auto (dog) & $\begin{array}{l}\sqrt{ } \quad \begin{array}{l}\text { Normoglycemic rats } 86 \% \text { at } 1 \text { year } \\
\text { after transplantation }\end{array}\end{array}$ \\
\hline $\begin{array}{l}\text { Motojima K et al. } \\
\text { [101] }\end{array}$ & 1992 & Auto (dog) & $\sqrt{ } \quad$ Normoglycemia not achieved \\
\hline $\begin{array}{l}\text { Marchetti P et al. } \\
{[102]}\end{array}$ & 1993 & Auto (dog) & $\begin{array}{ll}\sqrt{ } \quad \begin{array}{l}\text { Normoglycemic rate } 90 \% \text {, and } \\
\text { decreased to } 71 \% \text { at } 1 \text { year }\end{array} \\
\text { after transplantation }\end{array}$ \\
\hline Ao Z et al. [56] & 1993 & Auto (dog) & $\sqrt{ } \quad$ Normoglycemic rate $67 \%$ \\
\hline $\begin{array}{l}\text { Yakimets WJ et al. } \\
\text { [117] }\end{array}$ & 1993 & Allo (dog) & $\begin{array}{l}\sqrt{ } \quad \begin{array}{l}\text { Approximate } 20 \text { days graft survival } \\
\text { using cyclosporine and rapamycin }\end{array}\end{array}$ \\
\hline $\begin{array}{l}\text { Hesse UJ et al. } \\
\text { [111] }\end{array}$ & 1994 & Auto (pig) & $\sqrt{ } \quad$ The normoglycemic rate was $50 \%$. \\
\hline $\begin{array}{l}\text { Eizirik DL et al. } \\
{[128]}\end{array}$ & 1997 & $\begin{array}{l}\text { Xeno, allo (human } \\
\text { and mouse-to-nude } \\
\text { mouse) }\end{array}$ & $\begin{array}{ll}\sqrt{ } & \text { Normoglycemia achieved by } \\
\text { transplantation of } 300 \text { human islets } \\
\text { into renal subcapsular space or } 200 \\
\text { mouse islets into pulp of the spleen }\end{array}$ \\
\hline Horton PJ et al. [77] & 2000 & Allo (dog) & 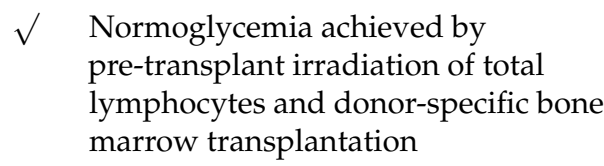 \\
\hline
\end{tabular}

However, although the spleen has many advantages over other transplant sites, the efficacy of transplantation has been somewhat unclear. For example, Evans and colleagues showed that the transplantation efficacy into the spleen was better than that into the liver or kidney in an islet autotransplantation dog model: $90 \%$ of animals achieved normoglycemia at one month for the spleen compared with 33\% for liver and 0\% for kidney [96] (Table 3). Using fetal porcine allotransplantation and murine transplantation models, Stokes et al. showed a higher transplantation efficacy for the spleen compared with the liver, although the kidney was better $[129,130]$. Many other studies have reported superiority of the spleen compared with the liver $[100,111]$ or omental pouch $[56,131]$, although some groups have reported opposite results [97-99] (Table 3).

The route of transplantation into the spleen also needs to be considered. The earliest studies transplanted islets into the spleen pulp [90,92]. However, Warnock et al. tested intrasplenic islet transplantation via the splenic vein in an islet autotransplanted pancreatectomized dog model, and observed greater efficacy versus transplantation into the pulp, achieving normoglycemia in $86 \%$ vs. 33\% of animals [122] (Table 2). Although the intravenous route has been considered to show greater efficacy for intrasplenic transplantation than the intrapulp route, the intravenous route can increase 
the risk of IBMIR, which can damage the transplanted islets, similar to intraportal transplantation into the liver [55].

Table 3. Efficacy of intrasplenic islet transplantation.

\begin{tabular}{|c|c|c|c|}
\hline $\begin{array}{l}\text { Authors } \\
\text { [Reference] }\end{array}$ & $\begin{array}{l}\text { Publication } \\
\text { Year }\end{array}$ & Transplant model & Comments \\
\hline $\begin{array}{l}\text { Sutton R et al. } \\
\text { [114] }\end{array}$ & 1989 & $\begin{array}{l}\text { vs. Liver (auto, } \\
\text { monkey) }\end{array}$ & $\begin{array}{l}\text { Intrasplenic transplantation showed no } \\
\text { superiority over intraportal transplantation }\end{array}$ \\
\hline $\begin{array}{l}\text { Evans MG et al. } \\
\text { [96] }\end{array}$ & 1989 & $\begin{array}{l}\text { vs. Liver, kidney (auto, } \\
\text { dog) }\end{array}$ & $\begin{array}{ll}\sqrt{ } \quad & \text { Transplantation efficacy better in intrasplenic } \\
\text { transplanted dog model: } 90 \% \text { achieved } \\
\text { normoglycemia at } 1 \text { month, compared with } \\
33 \% \text { for intraportal and } 0 \% \text { for } \\
\text { renal subcapsular }\end{array}$ \\
\hline $\begin{array}{l}\text { van der Vliet JA } \\
\text { et al. }[97,98]\end{array}$ & 1989 & vs. Liver (auto, dog) & $\begin{array}{ll}\sqrt{ } \quad \text { Normoglycemic rate } 63 \% \text { for intrasplenic vs. } \\
75 \% \text { for intraportal }\end{array}$ \\
\hline $\begin{array}{l}\text { Warnock GL et al. } \\
\text { [99] }\end{array}$ & 1990 & vs. Liver (auto, dog) & $\begin{array}{ll}\sqrt{ } \quad \begin{array}{l}\text { Normoglycemic rate } 63 \% \text { for intrasplenic vs. } \\
80 \% \text { for intraportal }\end{array} \\
\sqrt{ } \quad \begin{array}{l}\text { Hyperglycemia after transplantation was less } \\
\text { severe and onset was delayed }\end{array}\end{array}$ \\
\hline $\begin{array}{l}\text { Scharp DW et al. } \\
\text { [100] }\end{array}$ & 1992 & vs. Liver (auto, dog) & $\begin{array}{ll}\sqrt{ } \quad & \text { Normoglycemic rate } 86 \% \text { for intrasplenic vs. } \\
& 50 \% \text { for intraportal at } 1 \text { year } \\
& \text { after transplantation }\end{array}$ \\
\hline $\begin{array}{l}\text { Motojima K et al. } \\
\text { [101] }\end{array}$ & 1992 & vs. Liver (Auto, dog) & $\begin{array}{ll}\sqrt{ } \quad \begin{array}{l}\text { Normoglycemia not achieved with either } \\
\text { intrasplenic or intraportal transplantation }\end{array}\end{array}$ \\
\hline Ao Z et al. [56] & 1993 & $\begin{array}{l}\text { vs. Omental pouch } \\
\text { (auto, dog) }\end{array}$ & $\begin{array}{ll}\sqrt{ } \quad \text { Normoglycemic rate } 67 \% \text { for intrasplenic vs. } \\
50 \% \text { for intraomental transplantation }\end{array}$ \\
\hline $\begin{array}{l}\text { Hesse UJ et al. } \\
\text { [111] }\end{array}$ & 1994 & vs. Liver (auto, pig) & $\begin{array}{l}\sqrt{ } \quad \text { Normoglycemic rate } 50 \% \text { for intrasplenic vs. } \\
25 \% \text { for intraportal transplantation }\end{array}$ \\
\hline $\begin{array}{l}\text { Gustavson SM } \\
\text { et al. [131] }\end{array}$ & 2005 & $\begin{array}{l}\text { vs. Omental pouch } \\
\text { (auto, dog) }\end{array}$ & $\begin{array}{ll}\sqrt{ } & \text { Transplantation efficacy better for } \\
\text { intrasplenic versus intraomental pouch } \\
\text { transplantation as assessed by glucose } \\
\text { tolerance test }\end{array}$ \\
\hline $\begin{array}{l}\text { Stokes RA et al. } \\
\text { [129] }\end{array}$ & 2017 & $\begin{array}{l}\text { vs. Liver, kidney (Allo, } \\
\text { pig) }\end{array}$ & $\begin{array}{ll}\sqrt{ } \quad \begin{array}{l}\text { Allo-transplant model using fetal porcine } \\
\text { islets. Transplantation efficacy was kidney }> \\
\text { spleen }>\text { liver }\end{array}\end{array}$ \\
\hline $\begin{array}{l}\text { Stokes RA et al. } \\
\text { [130] }\end{array}$ & 2017 & $\begin{array}{l}\text { vs. Liver, kidney (iso, } \\
\text { mouse) } \\
\text { vs. Liver, kidney, } \\
\text { portal vein, muscle } \\
\text { (xeno, human-to-SCID } \\
\text { mouse) }\end{array}$ & $\begin{array}{ll}\sqrt{ } \quad \begin{array}{l}\text { Iso: transplantation of } 220-250 \text { islets. } \\
\text { Normoglycemia rate } 100 \% \text { in kidney, } 29 \% \text { in } \\
\text { spleen, } 0 \% \text { in liver (subcapsular space was }\end{array} \\
\text { used in the spleen and liver } \\
\text { transplant models) } \\
\sqrt{ } \quad \begin{array}{l}\text { Xeno: transplantation of human } 2000 \text { islets. } \\
\text { Normoglycemia rate } 100 \% \text { for kidney, } 70 \%\end{array} \\
\text { for muscle, and } 60 \% \text { for portal vein }\end{array}$ \\
\hline
\end{tabular}

To examine the potential usefulness of the spleen as an islet transplantation site and to try to develop a better procedure for intrasplenic transplantation, we explored the "splenic subcapsular implantation technique" using a rodent syngeneic transplant model, and analyzed the transplant efficacy of this method compared with intrahepatic and renal subcapsular transplantation [83]. This 
procedure involved direct puncture from the surface with a 27-gauge needle and implantation of islets under the splenic surface without venous or pulp injury (Figure 2).

\section{A. Procedure of splenic subcapsular implantation technique}

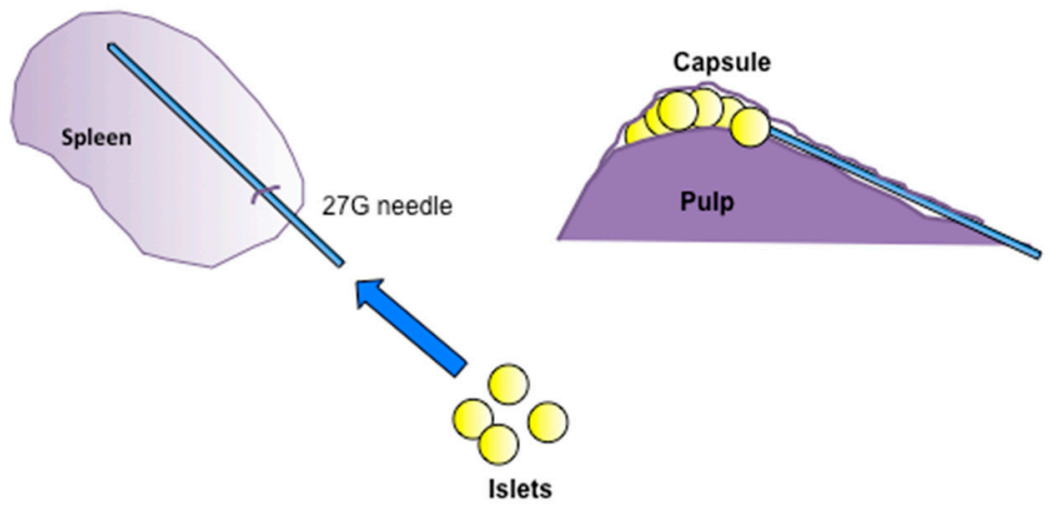

\section{B. Engrafted islets under the capsule of spleen}
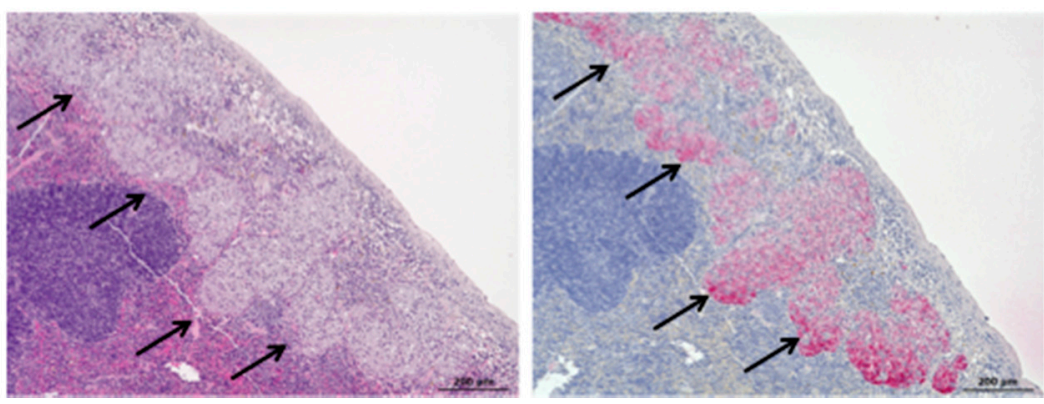

Figure 2. (A) Splenic subcapsular implantation technique; and (B) Engrafted islets (d arrows) under the spleen capsule 28 days after transplantation ((Left) hematoxylin and eosin staining; and (right) immunostaining for insulin). Scale bar $200 \mu \mathrm{m}$.

Notably, all the transplanted mice $(n=10)$ achieved normoglycemia for two months, even after intrasplenic transplantation of only 50 islets. In contrast, none of the mice transplanted with islets into the liver or kidney achieved normoglycemia. Intrasplenic transplantation was thus not only superior to other sites in terms of transplantation efficacy, but also allowed three to four diabetic mice to be treated using islets from a single donor mouse (i.e., 150-200 islets can be harvested from one donor mouse). Normoglycemia could also be achieved using as few as 25 islets transplanted into the spleen if glucose levels were also managed rigorously. Histological assessment revealed that the intrasplenic transplanted islets were enlarged in size. The transplantation efficacy of this model clearly exceeded those of previously reported intrapulp and intravenous transplantation models [99,120]. We speculated that this might be because intrapulp and intravenous transplantation involve greater tissue damage and consequent exposure of islets to the blood compared with intrasplenic transplantation, thus inducing IBMIR. In addition to preventing graft loss, intrasplenic transplantation allows the engrafted islets to access a rich oxygen and nutrient supply associated with the abundant blood flow. These factors, together with the privileged immune status of this site, may explain the greater success of engraftment and regeneration.

The spleen has a hard elastic capsule, like the kidney [132]. Although this can be an obstacle in terms of the number of islets it is able to contain, we suggest that this cannot be a major limitation. In contrast to the kidney, the spleen has a softer parenchyma, which provides sufficient space to 
accommodate many islets, and the hardness of the capsule is therefore not a limitation of intrasplenic islet transplantation using the splenic subcapsular implantation technique.

Regarding the possibility of an intraarterial approach for intrasplenic islet transplantation, Wang and colleagues recently assessed the therapeutic effects of transarterial chemoembolization in patients with unresectable hepatocellular carcinoma using transcatheter intraarterial perfusion magnetic resonance imaging, and demonstrated the usefulness of the imaging examination for showing changes in tumor perfusion [133]. This methodology has three merits in terms of its application to islet transplantation: the transcatheter procedure can be performed under local anesthesia; the target organ for islet transplantation can be selected by the transcatheter procedure (intrasplenic islet transplantation can be done by cannulation of the catheter into the splenic artery); and the condition of the islets after transplantation can be assessed by intraarterial perfusion magnetic resonance imaging. Although there have been no reports of intraarterial islet transplantation to date, it may become an option for islet transplantation, with future modifications.

\section{Future Clinical Intrasplenic Islet Transplantation}

The first intrasplenic islet transplantation was performed in a clinical setting at the University of Leicester 20 years ago. Five chronic pancreatitis patients underwent spleen-preserving total pancreatectomy and intrasplenic islet autotransplantation, of whom two achieved insulin independence for over a year. However, this procedure was associated with high morbidity, including splenic infarction and portal thrombosis [37]. Du Toit et al. reported that intrasplenic islet transplantation was accompanied by life-threatening complications, including subcapsular hematoma, intrasplenic necrosis and cavitation, capsular perforation and arteriolar thrombosis [115]. However, we believe these complications could be overcome with advances in surgical procedures. In our opinion, implantation into the splenic subcapsular region may minimize the risk of necrosis, thrombosis and hemorrhage by preventing venous and pulp injury. Laparoscopic surgery or intraportal transplantation could also minimize the surgical stress of the transplantation procedure. We suggest that, using a combination of the techniques described here, intrasplenic transplantation may offer the optimal approach to islet transplantation.

The spleen has historically been an important site for islet transplantation, but its utility could be greatly improved by the application of recent novel findings and techniques, and we therefore advocate the development of clinical methods to optimize the safe and effective transplantation of islets into the spleen.

\section{Spleen as a Source of Mesenchymal Stem Cells}

We also considered the importance of splenic mesenchymal stem cells. As noted in Section 4, the spleen acts as a stem cell reservoir as well as an islet transplant site. The spleen harbors both hematopoietic and mesenchymal stem cells, with and without CD45 labeling, respectively. CD45splenic mesenchymal stem cells play an important role in the repair of damaged tissues, as in other organs including the bone marrow and adipose tissue. The first step of tissue repair involves the migration of mesenchymal stem cells specifically into the damaged tissue. Mesenchymal stem cells are believed to detect signals released from the damaged tissue, which cause them to migrate and accumulate selectively in the damaged tissue. The representative signal is HMGB1, which interacts with the nucleosome, transcription factors and histones. HMGB1 influences the structure and remodeling of chromatin by binding to its internucleosomal linker regions to facilitate nucleosome sliding [134]. HMGB1 released from damaged and apoptotic tissues has been shown to activate nuclear factor-kappa $\mathrm{B}$ by binding to toll-like receptor 4 and receptor for advanced glycation endproducts expressed on the surface of immune and inflammatory cells, subsequently causing an immune response and inflammatory reaction, and removing damaged and apoptotic tissues [135]. This sequential reaction requires binding between HMGB1 and damaged-tissue-derived DNA and histone protein [136]. Meanwhile, free HMGB1 released from the damaged tissue promotes the migration of mesenchymal 
stem cells to the damaged tissue and tissue repair [137] (Figure 3). The migration of splenic stem cells is considered to be controlled by HMGB1, especially in the case of inadequately functioning bone marrow due to disease [138].

Following migration to the damaged tissue, splenic mesenchymal stem cells differentiate into the cellular components of the damaged tissue. We previously showed that these cells differentiated into islets [78] and salivary epithelial cells [139]. Regarding islets, syngeneic CD45- splenic stem cells infused into NOD mice migrated into islets damaged as a result of autoimmunity and differentiated into insulin-positive $\beta$ cells [78] (Figure 3). Robertson and colleagues also showed that dissected quail splenic tissue (presumably including mesenchymal stem cells) differentiated into insulin-producing cells under co-culture with chick pancreatic epithelium [140]. Regarding the salivary gland, we showed that infused splenocytes migrated into damaged salivary glands in NOD mice, as an animal model of Sjogren's syndrome [141], and differentiated into salivary epithelial cells [139] (Figure 3). Sjogren's syndrome is an autoimmune disease that destroys salivary and lachrymal glands, resulting in dry eyes and mouth, which symptoms drastically impair patient quality of life. Dry eyes can lead to vision problems including loss of light sensitivity, blurred vision and corneal damage, while dry mouth induces dental caries and oral infection. Tissue repair of the salivary glands can prevent these symptoms and thus improve quality of life, and mesenchymal stem cells may thus be a promising therapy for Sjogren's syndrome. A novel clinical trial of mesenchymal stem cell infusion therapy was recently applied in Sjogren's syndrome patients [142]. Given the lack of radical new treatments for Sjogren's syndrome, mesenchymal stem cell infusion therapy may offer a promising therapeutic strategy for these patients.

CD45- splenic stem cells express OCT3/4, SOX2, KLF4, c-MYC and NANOG proteins, which induce matured cells into induced pluripotent stem cells [84], as well as transcription factors also identified in embryonic stem cells, including HOX11. HOX11 (TLX1), similar to other HOXA subgroups including HOX11L2 (TLX3), is an oncogene that induces T-cell acute lymphoblastic leukemia (T-ALL) by chromosomal translocation of $\mathrm{t}(10 ; 14)(\mathrm{q} 24 ; \mathrm{q} 11)$ and $\mathrm{t}(7 ; 10)(\mathrm{q} 35 ; \mathrm{q} 24)$ [143]. According to Cancer Research UK, the prognosis of T-ALL is relatively good (five-year survival rate after diagnosis 70\%; http://www.cancerresearchuk.org/about-cancer/acute-lymphoblastic-leukaemia-all/survival). Notably, Ferrando and colleagues revealed that the survival rate of HOX11-positive T-ALL patients was significantly better than that of other T-ALL patients ( $88 \%$ vs. $56 \%, p=0.019)$ [144]. This suggests that HOX11 is a risk factor for T-ALL, but can also be used as a marker for evaluating patient prognosis. HOX11 is an embryonic protein that contributes to embryonic development, including cell survival, differentiation and regeneration $[145,146]$. HOX11-positive mesenchymal stem cells are located under the splenic capsule rather than in the pulp of the spleen [84] (Figure 3), and HOX11 is expressed specifically in CD45- splenic mesenchymal stem cells, and not in stem cells from other organs, including the bone marrow and liver [84,85]. HOX11-positive cells are considered to be a major component of the CD45- splenic mesenchymal stem cells that contribute to tissue repair of damaged islets and salivary glands in our models.

The main disadvantage associated with the clinical application of splenic mesenchymal stem cells is the cumbersome nature of the procedure compared with bone marrow or adipose mesenchymal stem cells. Splenectomy is essential for acquiring mesenchymal stem cells, but it is difficult to collect donor spleen. Although splenectomy is indicated for pancreatic and splenic malignant diseases, hematologic diseases such as idiopathic thrombocytopenic purpura and injury, malignant diseases are excluded as indications. Moreover, splenectomy should not be carried out in healthy donors because of the need for laparotomy or laparoscopic surgery under general anesthesia, and potential complications including overwhelming postsplenectomy infection. However, one possible use of splenic mesenchymal stem cells may be autotransplantation in patients with benign diseases, such as injury. Cloning and banking of splenic stem cells is also a promising method for utilizing the cells as required. 


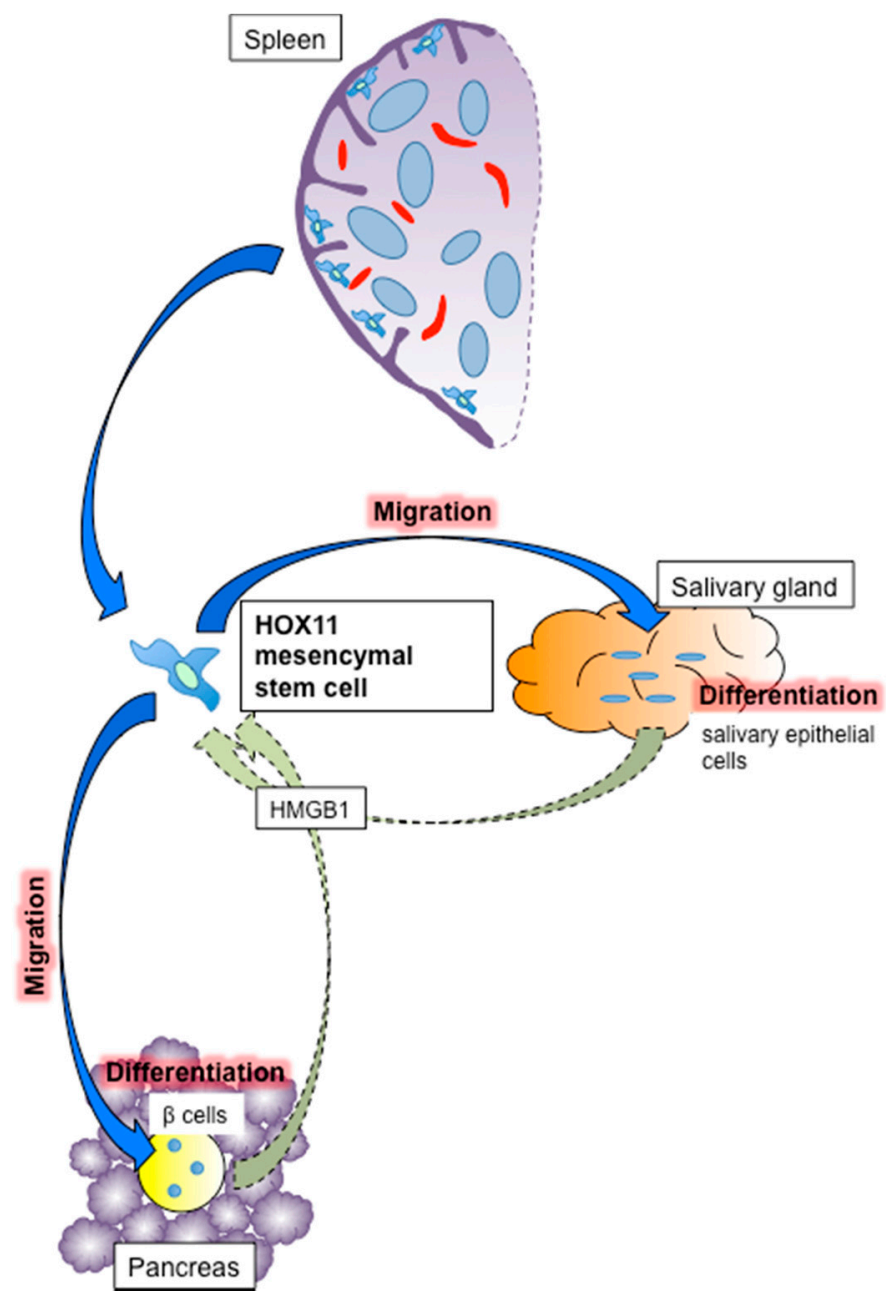

Figure 3. Mechanism of tissue repair by splenic mesenchymal stem cells. Splenic mesenchymal stem cells are normally located under the splenic capsule and migrate to the damaged tissue following stimulation by HMGB1. They then differentiate into tissue components such as $\beta$ cells in pancreatic islets and salivary epithelial cells in salivary glands. HOX11-positive cells are considered to be splenic mesenchymal stem cells.

\section{Conclusions}

In this review, we demonstrate the importance of the spleen as an optimal site for islet transplantation and as a source of mesenchymal stem cells. Although the spleen has been considered as an unnecessary organ, it has many unique potentials in experimental and clinical medicine. Further studies are needed to clarify these potential applications of the spleen.

Author Contributions: N.S. designed this review and wrote the first draft of this manuscript. G.Y. revised the manuscript and designed Figure 2. S.K. checked the draft as the final version.

Acknowledgments: This study was supported by a Challenging Research (Exploratory) (17K19692, Naoaki Sakata), a Grant-in-Aid for Scientific Research (B) (26293294, Shohta Kodama) from the Ministry of Education, Culture, Sports, Science and Technology of Japan and intramural funds from Fukuoka University. We thank Hiroyuki Takahashi, Taisuke Matsuoka, Hideaki Yamada, Ryo Kawakami, Ayana Esaki and Yumie Tamura for support with our research. We also thank Susan Furness, PhD, from Edanz Group (www.edanzediting.com/ac) for editing a draft of this manuscript.

Conflicts of Interest: The authors declare no conflict of interest. 


\section{Abbreviations}

$\begin{array}{ll}\text { HMGB1 } & \text { high-mobility group box } 1 \\ \text { IBMIR } & \text { instant blood-mediated inflammatory reaction } \\ \text { IL } & \text { interleukin } \\ \text { NOD } & \text { non-obese } \\ \text { Rrm2b } & \text { ribonucleoside-diphosphate reductase subunit M2 b } \\ \text { T-ALL } & \text { T-cell acute lymphoblastic leukemia } \\ \text { Tregs } & \text { regulatory T cells }\end{array}$

\section{References}

1. Golub, R.; Tan, J.; Watanabe, T.; Brendolan, A. Origin and Immunological Functions of Spleen Stromal Cells. Trends Immunol. 2018. [CrossRef] [PubMed]

2. Newland, A.; Provan, D.; Myint, S. Preventing severe infection after splenectomy. BMJ 2005, 331, 417-418. [CrossRef] [PubMed]

3. Tarantino, G.; Scalera, A.; Finelli, C. Liver-spleen axis: Intersection between immunity, infections and metabolism. World J. Gastroenterol. 2013, 19, 3534-3542. [CrossRef] [PubMed]

4. Fiorina, P.; Shapiro, A.M.; Ricordi, C.; Secchi, A. The clinical impact of islet transplantation. Am. J. Transplant. 2008, 8, 1990-1997. [CrossRef] [PubMed]

5. Fiorina, P.; Folli, F.; Bertuzzi, F.; Maffi, P.; Finzi, G.; Venturini, M.; Socci, C.; Davalli, A.; Orsenigo, E.; Monti, L.; et al. Long-term beneficial effect of islet transplantation on diabetic macro-/microangiopathy in type 1 diabetic kidney-transplanted patients. Diabetes Care 2003, 26, 1129-1136. [CrossRef] [PubMed]

6. Fiorina, P.; Folli, F.; Zerbini, G.; Maffi, P.; Gremizzi, C.; Di Carlo, V.; Socci, C.; Bertuzzi, F.; Kashgarian, M.; Secchi, A. Islet transplantation is associated with improvement of renal function among uremic patients with type I diabetes mellitus and kidney transplants. J. Am. Soc. Nephrol. 2003, 14, 2150-2158. [CrossRef] [PubMed]

7. Sutherland, D.E.; Radosevich, D.M.; Bellin, M.D.; Hering, B.J.; Beilman, G.J.; Dunn, T.B.; Chinnakotla, S.; Vickers, S.M.; Bland, B.; Balamurugan, A.N.; et al. Total pancreatectomy and islet autotransplantation for chronic pancreatitis. J. Am. Coll. Surg. 2012, 214, 409-424. [CrossRef] [PubMed]

8. Ricordi, C.; Strom, T.B. Clinical islet transplantation: Advances and immunological challenges. Nat. Rev. Immunol. 2004, 4, 259-268. [CrossRef] [PubMed]

9. Ricordi, C.; Lacy, P.E.; Finke, E.H.; Olack, B.J.; Scharp, D.W. Automated method for isolation of human pancreatic islets. Diabetes 1988, 37, 413-420. [CrossRef] [PubMed]

10. Scharp, D.W.; Lacy, P.E.; Santiago, J.V.; McCullough, C.S.; Weide, L.G.; Falqui, L.; Marchetti, P.; Gingerich, R.L.; Jaffe, A.S.; Cryer, P.E.; et al. Insulin independence after islet transplantation into type I diabetic patient. Diabetes 1990, 39, 515-518. [CrossRef] [PubMed]

11. Tzakis, A.G.; Ricordi, C.; Alejandro, R.; Zeng, Y.; Fung, J.J.; Todo, S.; Demetris, A.J.; Mintz, D.H.; Starzl, T.E. Pancreatic islet transplantation after upper abdominal exenteration and liver replacement. Lancet 1990, 336, 402-405. [CrossRef]

12. Ekmekcioglu, O.; Turkan, S.; Yildiz, S.; Gunes, Z.E. Comparison of tacrolimus with a cyclosporine microemulsion for immunosuppressive therapy in kidney transplantation. Turk. J. Urol. 2013, 39, 16-21. [CrossRef] [PubMed]

13. Bergmann, T.K.; Isbel, N.M.; Barraclough, K.A.; Campbell, S.B.; McWhinney, B.C.; Staatz, C.E. Comparison of the influence of cyclosporine and tacrolimus on the pharmacokinetics of prednisolone in adult male kidney transplant recipients. Clin. Drug Investig. 2014, 34, 183-188. [CrossRef] [PubMed]

14. Shapiro, A.M.; Lakey, J.R.; Ryan, E.A.; Korbutt, G.S.; Toth, E.; Warnock, G.L.; Kneteman, N.M.; Rajotte, R.V. Islet transplantation in seven patients with type 1 diabetes mellitus using a glucocorticoid-free immunosuppressive regimen. N. Engl. J. Med. 2000, 343, 230-238. [CrossRef] [PubMed]

15. Kahan, B.D. Sirolimus: A comprehensive review. Expert Opin. Pharmacother. 2001, 2, 1903-1917. [CrossRef] [PubMed]

16. Mukherjee, S.; Mukherjee, U. A comprehensive review of immunosuppression used for liver transplantation. J. Transplant. 2009, 2009, 701464. [CrossRef] [PubMed] 
17. Milo, R.; Osherov, M. Daclizumab and its use in multiple sclerosis treatment. Drugs Today (Barc) 2017, 53, 7-18. [CrossRef] [PubMed]

18. Bellin, M.D.; Kandaswamy, R.; Parkey, J.; Zhang, H.J.; Liu, B.; Ihm, S.H.; Ansite, J.D.; Witson, J.; Bansal-Pakala, P.; Balamurugan, A.N.; et al. Prolonged insulin independence after islet allotransplants in recipients with type 1 diabetes. Am. J. Transplant. 2008, 8, 2463-2470. [CrossRef] [PubMed]

19. Semenkow, S.; Li, S.; Kahlert, U.D.; Raabe, E.H.; Xu, J.; Arnold, A.; Janowski, M.; Oh, B.C.; Brandacher, G.; Bulte, J.W.M.; et al. An immunocompetent mouse model of human glioblastoma. Oncotarget 2017, 8, 61072-61082. [CrossRef] [PubMed]

20. Ryan, E.A.; Paty, B.W.; Senior, P.A.; Bigam, D.; Alfadhli, E.; Kneteman, N.M.; Lakey, J.R.; Shapiro, A.M. Five-year follow-up after clinical islet transplantation. Diabetes 2005, 54, 2060-2069. [CrossRef] [PubMed]

21. Barton, F.B.; Rickels, M.R.; Alejandro, R.; Hering, B.J.; Wease, S.; Naziruddin, B.; Oberholzer, J.; Odorico, J.S.; Garfinkel, M.R.; Levy, M.; et al. Improvement in outcomes of clinical islet transplantation: 1999-2010. Diabetes Care 2012, 35, 1436-1445. [CrossRef] [PubMed]

22. Balamurugan, A.N.; Naziruddin, B.; Lockridge, A.; Tiwari, M.; Loganathan, G.; Takita, M.; Matsumoto, S.; Papas, K.; Trieger, M.; Rainis, H.; et al. Islet product characteristics and factors related to successful human islet transplantation from the Collaborative Islet Transplant Registry (CITR) 1999-2010. Am. J. Transplant. 2014, 14, 2595-2606. [CrossRef] [PubMed]

23. Mellgren, A.; Schnell Landstrom, A.H.; Petersson, B.; Andersson, A. The renal subcapsular site offers better growth conditions for transplanted mouse pancreatic islet cells than the liver or spleen. Diabetologia 1986, 29, 670-672. [CrossRef] [PubMed]

24. Hiller, W.F.; Klempnauer, J.; Luck, R.; Steiniger, B. Progressive deterioration of endocrine function after intraportal but not kidney subcapsular rat islet transplantation. Diabetes 1991, 40, 134-140. [CrossRef] [PubMed]

25. Kemp, C.B.; Knight, M.J.; Scharp, D.W.; Ballinger, W.F.; Lacy, P.E. Effect of transplantation site on the results of pancreatic islet isografts in diabetic rats. Diabetologia 1973, 9, 486-491. [CrossRef] [PubMed]

26. Yasunami, Y.; Lacy, P.E.; Finke, E.H. A new site for islet transplantation-A peritoneal-omental pouch. Transplantation 1983, 36, 181-182. [CrossRef] [PubMed]

27. Kin, T.; Korbutt, G.S.; Rajotte, R.V. Survival and metabolic function of syngeneic rat islet grafts transplanted in the omental pouch. Am. J. Transplant. 2003, 3, 281-285. [CrossRef] [PubMed]

28. Osama Gaber, A.; Chamsuddin, A.; Fraga, D.; Fisher, J.; Lo, A. Insulin independence achieved using the transmesenteric approach to the portal vein for islet transplantation. Transplantation 2004, 77, 309-311. [CrossRef] [PubMed]

29. Fujita, M.; McGrath, K.M.; Bottino, R.; Dons, E.M.; Long, C.; Kumar, G.; Ekser, B.; Echeverri, G.J.; Hata, J.; Haruma, K.; et al. Technique of endoscopic biopsy of islet allografts transplanted into the gastric submucosal space in pigs. Cell Transplant. 2013, 22, 2335-2344. [CrossRef] [PubMed]

30. Sakata, N.; Aoki, T.; Yoshimatsu, G.; Tsuchiya, H.; Hata, T.; Katayose, Y.; Egawa, S.; Unno, M. Strategy for clinical setting in intramuscular and subcutaneous islet transplantation. Diabetes Metab. Res. Rev. 2014, 30, 1-10. [CrossRef] [PubMed]

31. Mojibian, M.; Harder, B.; Hurlburt, A.; Bruin, J.E.; Asadi, A.; Kieffer, T.J. Implanted islets in the anterior chamber of the eye are prone to autoimmune attack in a mouse model of diabetes. Diabetologia 2013, 56, 2213-2221. [CrossRef] [PubMed]

32. Xin, Z.L.; Ge, S.L.; Wu, X.K.; Jia, Y.J.; Hu, H.T. Intracerebral xenotransplantation of semipermeable membraneencapsuled pancreatic islets. World J. Gastroenterol. 2005, 11, 5714-5717. [CrossRef] [PubMed]

33. Bobzien, B.; Yasunami, Y.; Majercik, M.; Lacy, P.E.; Davie, J.M. Intratesticular transplants of islet xenografts (rat to mouse). Diabetes 1983, 32, 213-216. [CrossRef] [PubMed]

34. Ferguson, J.; Scothorne, R.J. Extended survival of pancreatic islet allografts in the testis of guinea-pigs. J. Anat. 1977, 124 Pt 1, 1-8. [PubMed]

35. Cantarelli, E.; Citro, A.; Pellegrini, S.; Mercalli, A.; Melzi, R.; Dugnani, E.; Jofra, T.; Fousteri, G.; Mondino, A.; Piemonti, L. Transplant Site Influences the Immune Response After Islet Transplantation: Bone Marrow Versus Liver. Transplantation 2017, 101, 1046-1055. [CrossRef] [PubMed] 
36. Levy, M.M.; Ketchum, R.J.; Tomaszewski, J.E.; Naji, A.; Barker, C.F.; Brayman, K.L. Intrathymic islet transplantation in the canine: I. Histological and functional evidence of autologous intrathymic islet engraftment and survival in pancreatectomized recipients. Transplantation 2002, 73, 842-852. [CrossRef] [PubMed]

37. White, S.A.; London, N.J.; Johnson, P.R.; Davies, J.E.; Pollard, C.; Contractor, H.H.; Hughes, D.P.; Robertson, G.S.; Musto, P.P.; Dennison, A.R. The risks of total pancreatectomy and splenic islet autotransplantation. Cell Transplant. 2000, 9, 19-24. [CrossRef] [PubMed]

38. Owen, R.J.; Ryan, E.A.; O’Kelly, K.; Lakey, J.R.; McCarthy, M.C.; Paty, B.W.; Bigam, D.L.; Kneteman, N.M.; Korbutt, G.S.; Rajotte, R.V.; et al. Percutaneous transhepatic pancreatic islet cell transplantation in type 1 diabetes mellitus: Radiologic aspects. Radiology 2003, 229, 165-170. [CrossRef] [PubMed]

39. Schramm, R.; Scheuer, C.; Yamauchi, J.; Vollmar, B.; Menger, M.D. Heat shock preconditioning impairs revascularization of freely transplanted pancreatic islets. Transplantation 2002, 74, 1544-1550. [CrossRef] [PubMed]

40. Carlsson, P.O.; Palm, F.; Andersson, A.; Liss, P. Markedly decreased oxygen tension in transplanted rat pancreatic islets irrespective of the implantation site. Diabetes 2001, 50, 489-495. [CrossRef] [PubMed]

41. Sakata, N.; Hayes, P.; Tan, A.; Chan, N.K.; Mace, J.; Peverini, R.; Sowers, L.; Pearce, W.J.; Chinnock, R.; Obenaus, A.; et al. MRI assessment of ischemic liver after intraportal islet transplantation. Transplantation 2009, 87, 825-830. [CrossRef] [PubMed]

42. Sakata, N.; Obenaus, A.; Chan, N.; Mace, J.; Chinnock, R.; Hathout, E. Factors affecting islet graft embolization in the liver of diabetic mice. Islets 2009, 1, 26-33. [CrossRef] [PubMed]

43. Bottino, R.; Fernandez, L.A.; Ricordi, C.; Lehmann, R.; Tsan, M.F.; Oliver, R.; Inverardi, L. Transplantation of allogeneic islets of Langerhans in the rat liver: Effects of macrophage depletion on graft survival and microenvironment activation. Diabetes 1998, 47, 316-323. [CrossRef] [PubMed]

44. Fu, Y.; Lu, X.; Yi, S.; Wu, J.; O'Hara, J.M.; Hawthorne, W.J.; Hucker, K.; O'Connell, P.J. Selective rejection of porcine islet xenografts by macrophages. Xenotransplantation 2008, 15, 307-312. [CrossRef] [PubMed]

45. Ishiyama, K.; Rawson, J.; Omori, K.; Mullen, Y. Liver natural killer cells play a role in the destruction of islets after intraportal transplantation. Transplantation 2011, 91, 952-960. [CrossRef] [PubMed]

46. Bennet, W.; Sundberg, B.; Groth, C.G.; Brendel, M.D.; Brandhorst, D.; Brandhorst, H.; Bretzel, R.G.; Elgue, G.; Larsson, R.; Nilsson, B.; et al. Incompatibility between human blood and isolated islets of Langerhans: A finding with implications for clinical intraportal islet transplantation? Diabetes 1999, 48, 1907-1914. [CrossRef] [PubMed]

47. Johansson, H.; Lukinius, A.; Moberg, L.; Lundgren, T.; Berne, C.; Foss, A.; Felldin, M.; Kallen, R.; Salmela, K.; Tibell, A.; et al. Tissue factor produced by the endocrine cells of the islets of Langerhans is associated with a negative outcome of clinical islet transplantation. Diabetes 2005, 54, 1755-1762. [CrossRef] [PubMed]

48. Van der Windt, D.J.; Bottino, R.; Casu, A.; Campanile, N.; Cooper, D.K. Rapid loss of intraportally transplanted islets: An overview of pathophysiology and preventive strategies. Xenotransplantation 2007, 14, 288-297. [CrossRef] [PubMed]

49. Desai, N.M.; Goss, J.A.; Deng, S.; Wolf, B.A.; Markmann, E.; Palanjian, M.; Shock, A.P.; Feliciano, S.; Brunicardi, F.C.; Barker, C.F.; et al. Elevated portal vein drug levels of sirolimus and tacrolimus in islet transplant recipients: Local immunosuppression or islet toxicity? Transplantation 2003, 76, 1623-1625. [CrossRef] [PubMed]

50. Ryan, E.A.; Lakey, J.R.; Paty, B.W.; Imes, S.; Korbutt, G.S.; Kneteman, N.M.; Bigam, D.; Rajotte, R.V.; Shapiro, A.M. Successful islet transplantation: Continued insulin reserve provides long-term glycemic control. Diabetes 2002, 51, 2148-2157. [CrossRef] [PubMed]

51. Kawahara, T.; Kin, T.; Shapiro, A.M. A comparison of islet autotransplantation with allotransplantation and factors elevating acute portal pressure in clinical islet transplantation. J. Hepatobiliary Pancreat. Sci. 2012, 19, 281-288. [CrossRef] [PubMed]

52. Thomas, R.M.; Ahmad, S.A. Management of acute post-operative portal venous thrombosis. J. Gastrointest. Surg. 2010, 14, 570-577. [CrossRef] [PubMed]

53. Gray, D.W.; Sutton, R.; McShane, P.; Peters, M.; Morris, P.J. Exocrine contamination impairs implantation of pancreatic islets transplanted beneath the kidney capsule. J. Surg. Res. 1988, 45, 432-442. [CrossRef]

54. Jindal, R.M.; Sidner, R.A.; McDaniel, H.B.; Johnson, M.S.; Fineberg, S.E. Intraportal vs kidney subcapsular site for human pancreatic islet transplantation. Transplant. Proc. 1998, 30, 398-399. [CrossRef] 
55. Van der Windt, D.J.; Echeverri, G.J.; Ijzermans, J.N.; Cooper, D.K. The choice of anatomical site for islet transplantation. Cell Transplant. 2008, 17, 1005-1014. [CrossRef] [PubMed]

56. Ao, Z.; Matayoshi, K.; Lakey, J.R.; Rajotte, R.V.; Warnock, G.L. Survival and function of purified islets in the omental pouch site of outbred dogs. Transplantation 1993, 56, 524-529. [CrossRef] [PubMed]

57. Berman, D.M.; O’Neil, J.J.; Coffey, L.C.; Chaffanjon, P.C.; Kenyon, N.M.; Ruiz, P., Jr.; Pileggi, A.; Ricordi, C.; Kenyon, N.S. Long-term survival of nonhuman primate islets implanted in an omental pouch on a biodegradable scaffold. Am. J. Transplant. 2009, 9, 91-104. [CrossRef] [PubMed]

58. McQuilling, J.P.; Sittadjody, S.; Pareta, R.; Pendergraft, S.; Clark, C.J.; Farney, A.C.; Opara, E.C. Retrieval of Microencapsulated Islet Grafts for Post-transplant Evaluation. Methods Mol. Biol. 2017, 1479, 157-171. [PubMed]

59. Pareta, R.; McQuilling, J.P.; Sittadjody, S.; Jenkins, R.; Bowden, S.; Orlando, G.; Farney, A.C.; Brey, E.M.; Opara, E.C. Long-term function of islets encapsulated in a redesigned alginate microcapsule construct in omentum pouches of immune-competent diabetic rats. Pancreas 2014, 43, 605-613. [CrossRef] [PubMed]

60. Kobayashi, T.; Aomatsu, Y.; Iwata, H.; Kin, T.; Kanehiro, H.; Hisanga, M.; Ko, S.; Nagao, M.; Harb, G.; Nakajima, Y. Survival of microencapsulated islets at 400 days posttransplantation in the omental pouch of NOD mice. Cell Transplant. 2006, 15, 359-365. [CrossRef] [PubMed]

61. Weaver, J.D.; Headen, D.M.; Aquart, J.; Johnson, C.T.; Shea, L.D.; Shirwan, H.; Garcia, A.J. Vasculogenic hydrogel enhances islet survival, engraftment, and function in leading extrahepatic sites. Sci. Adv. 2017, 3, e1700184. [CrossRef] [PubMed]

62. Tanaka, T.; Fujita, M.; Bottino, R.; Piganelli, J.D.; McGrath, K.; Li, J.; Lee, W.; Iwase, H.; Wijkstrom, M.; Bertera, S.; et al. Endoscopic biopsy of islet transplants in the gastric submucosal space provides evidence of islet graft rejection in diabetic pigs. Islets 2016, 8, 1-12. [CrossRef] [PubMed]

63. Streilein, J.W. Unraveling immune privilege. Science 1995, 270, 1158-1159. [CrossRef] [PubMed]

64. Kaur, G.; Mital, P.; Dufour, J.M. Testisimmune privilege-Assumptions versus facts. Anim. Reprod. 2013, 10, 3-15. [PubMed]

65. Perez, V.L.; Saeed, A.M.; Tan, Y.; Urbieta, M.; Cruz-Guilloty, F. The eye: A window to the soul of the immune system. J. Autoimmun. 2013, 45, 7-14. [CrossRef] [PubMed]

66. Pachter, J.S.; de Vries, H.E.; Fabry, Z. The blood-brain barrier and its role in immune privilege in the central nervous system. J. Neuropathol. Exp. Neurol. 2003, 62, 593-604. [CrossRef] [PubMed]

67. Larocque, D.; Sanderson, N.S.; Bergeron, J.; Curtin, J.F.; Girton, J.; Wibowo, M.; Bondale, N.; Kroeger, K.M.; Yang, J.; Lacayo, L.M.; et al. Exogenous fms-like tyrosine kinase 3 ligand overrides brain immune privilege and facilitates recognition of a neo-antigen without causing autoimmune neuropathology. Proc. Natl. Acad. Sci. USA 2010, 107, 14443-14448. [CrossRef] [PubMed]

68. Hedger, M.P. Immunophysiology and pathology of inflammation in the testis and epididymis. J. Androl. 2011, 32, 625-640. [CrossRef] [PubMed]

69. Farooq, S.M.; Elkhatib, W.F.; Ashour, H.M. The in vivo and in vitro induction of anterior chamber associated immune deviation to myelin antigens in C57BL/6 mice. Brain Behav. Immun. 2014, 42, 118-122. [CrossRef] [PubMed]

70. Polonsky, K.S.; Given, B.D.; Hirsch, L.; Shapiro, E.T.; Tillil, H.; Beebe, C.; Galloway, J.A.; Frank, B.H.; Karrison, T.; Van Cauter, E. Quantitative study of insulin secretion and clearance in normal and obese subjects. J. Clin. Investig. 1988, 81, 435-441. [CrossRef] [PubMed]

71. Home, P.D. Plasma insulin profiles after subcutaneous injection: How close can we get to physiology in people with diabetes? Diabetes Obes. Metab. 2015, 17, 1011-1020. [CrossRef] [PubMed]

72. Thompson, H.S.; Harper, N.; Bevan, D.J.; Staines, N.A. Suppression of collagen induced arthritis by oral administration of type II collagen: Changes in immune and arthritic responses mediated by active peripheral suppression. Autoimmunity 1993, 16, 189-199. [CrossRef] [PubMed]

73. Miller, A.; al-Sabbagh, A.; Santos, L.M.; Das, M.P.; Weiner, H.L. Epitopes of myelin basic protein that trigger TGF-beta release after oral tolerization are distinct from encephalitogenic epitopes and mediate epitope-driven bystander suppression. J. Immunol. 1993, 151, 7307-7315. [PubMed]

74. Nagatani, K.; Dohi, M.; To, Y.; Tanaka, R.; Okunishi, K.; Nakagome, K.; Sagawa, K.; Tanno, Y.; Komagata, Y.; Yamamoto, K. Splenic dendritic cells induced by oral antigen administration are important for the transfer of oral tolerance in an experimental model of asthma. J. Immunol. 2006, 176, 1481-1489. [CrossRef] [PubMed] 
75. MacDonald, T.T. Suppressor T cells, rebranded as regulatory T cells, emerge from the wilderness bearing surface markers. Gut 2002, 51, 311-312. [CrossRef] [PubMed]

76. Takeuchi, Y.; Nishikawa, H. Roles of regulatory T cells in cancer immunity. Int. Immunol. 2016, 28, 401-409. [CrossRef] [PubMed]

77. Horton, P.J.; Hawthorne, W.J.; Walters, S.N.; Patel, A.T.; O'Connell, P.J.; Chapman, J.R.; Allen, R.D. Induction of allogeneic islet tolerance in a large-animal model. Cell Transplant. 2000, 9, 877-887. [CrossRef] [PubMed]

78. Kodama, S.; Kuhtreiber, W.; Fujimura, S.; Dale, E.A.; Faustman, D.L. Islet regeneration during the reversal of autoimmune diabetes in NOD mice. Science 2003, 302, 1223-1227. [CrossRef] [PubMed]

79. Ryu, S.; Kodama, S.; Ryu, K.; Schoenfeld, D.A.; Faustman, D.L. Reversal of established autoimmune diabetes by restoration of endogenous beta cell function. J. Clin. Investig. 2001, 108, 63-72. [CrossRef] [PubMed]

80. Itoh, T.; Iwahashi, S.; Kanak, M.A.; Shimoda, M.; Takita, M.; Chujo, D.; Tamura, Y.; Rahman, A.M.; Chung, W.Y.; Onaca, N.; et al. Elevation of high-mobility group box 1 after clinical autologous islet transplantation and its inverse correlation with outcomes. Cell Transplant. 2014, 23, 153-165. [CrossRef] [PubMed]

81. Matsuoka, N.; Itoh, T.; Watarai, H.; Sekine-Kondo, E.; Nagata, N.; Okamoto, K.; Mera, T.; Yamamoto, H.; Yamada, S.; Maruyama, I.; et al. High-mobility group box 1 is involved in the initial events of early loss of transplanted islets in mice. J. Clin. Investig. 2010, 120, 735-743. [CrossRef] [PubMed]

82. Itoh, T.; Nitta, T.; Nishinakamura, H.; Kojima, D.; Mera, T.; Ono, J.; Kodama, S.; Yasunami, Y. HMGB1-Mediated Early Loss of Transplanted Islets Is Prevented by Anti-IL-6R Antibody in Mice. Pancreas 2015, 44, 166-171. [CrossRef] [PubMed]

83. Itoh, T.; Nishinakamura, H.; Kumano, K.; Takahashi, H.; Kodama, S. The Spleen Is an Ideal Site for Inducing Transplanted Islet Graft Expansion in Mice. PLoS ONE 2017, 12, e0170899. [CrossRef] [PubMed]

84. Faustman, D.L.; Davis, M. Stem cells in the spleen: Therapeutic potential for Sjogren's syndrome, type I diabetes, and other disorders. Int. J. Biochem. Cell Biol. 2010, 42, 1576-1579. [CrossRef] [PubMed]

85. Kodama, S.; Davis, M.; Faustman, D.L. Diabetes and stem cell researchers turn to the lowly spleen. Sci. Aging Knowl. Environ. 2005, 2005, pe2. [CrossRef] [PubMed]

86. Lee, B.W.; Tan, S.H.; Lee, W.K.; Yap, H.K.; Aw, S.E.; Wong, H.B. Glucose tolerance test and insulin levels in children with transfusion-dependent thalassaemia. Ann. Trop. Paediatr. 1985, 5, 215-218. [CrossRef] [PubMed]

87. Wohlrab, F.; Schmidt, S.; Kloting, I.; Wilke, B.; Cossel, L. Ducto-insular proliferation of beta-cells after syngeneic islet transplantation into the spleen of streptozotocin-diabetic Lewis rats. Int. J. Pancreatol. 1989, 5 , 77-83. [PubMed]

88. Tanaka, H.; Arakawa, H.; Yamaguchi, T.; Shiraishi, K.; Fukuda, S.; Matsui, K.; Takei, Y.; Nakamura, Y. A ribonucleotide reductase gene involved in a p53-dependent cell-cycle checkpoint for DNA damage. Nature 2000, 404, 42-49. [CrossRef] [PubMed]

89. Kolb, E.; Ruckert, R.; Largiader, F. Intraportal and intrasplenic autotransplantation of pancreatic islets in the dog. Eur. Surg. Res. 1977, 9, 419-426. [CrossRef] [PubMed]

90. Feldman, S.D.; Hirshberg, G.E.; Dodi, G.; Raizman, M.E.; Scharp, D.W.; Ballinger, W.F.; Lacy, P.E. Intrasplenic islet isografts. Surgery 1977, 82, 386-394. [PubMed]

91. Schulak, J.A.; Stuart, F.P.; Reckard, C.R. Physiologic aspects of intrasplenic autotransplantation of pancreatic fragments in the dog after 24 hours of cold storage. J. Surg. Res. 1978, 24, 125-131. [CrossRef]

92. Gray, B.N.; Caruso, G.; Alford, F.; Chisholm, D. Insulin and glucagon responses of transplanted intrasplenic pancreatic islets. Arch. Surg. 1979, 114, 96-99. [CrossRef] [PubMed]

93. Merrell, R.C.; Marincola, F.; Maeda, M.; Cobb, L.; Basadonna, G. The metabolic response of intrasplenic islet autografts. Surg. Gynecol. Obstet. 1985, 160, 552-556. [PubMed]

94. Merrell, R.C.; Maeda, M.; Basadonna, G.; Marincola, F.; Cobb, L. Suppression, stress, and accommodation of transplanted islets of Langerhans. Diabetes 1985, 34, 667-670. [CrossRef] [PubMed]

95. Gores, P.F.; Boudreaux, J.P.; Hesse, U.J.; Najarian, J.S.; Sutherland, D.E. Canine islet autografts with and without administration of cyclosporine. Surgery 1987, 101, 557-561. [PubMed]

96. Evans, M.G.; Warnock, G.L.; Rajotte, R.V. Comparison of sites for transplantation of canine pancreatic microfragments. Diabetes Res. 1989, 10, 35-41. [PubMed] 
97. Van der Vliet, J.A.; Kaufman, D.B.; Meloche, R.M.; Heise, J.W.; Field, M.J.; Heil, J.E.; Najarian, J.S.; Sutherland, D.E. A simple method of canine pancreatic islet isolation and intrahepatic transplantation. J. Surg. Res. 1989, 46, 129-134. [CrossRef]

98. Van der Vliet, J.A.; Kaufman, D.B.; Meloche, R.M.; van der Hem, L.G.; Field, M.J.; Sutherland, D.E. Canine pancreatic islet transplantation: A comparison of two isolation techniques. Eur. Surg. Res. 1990, 22, 1-7. [CrossRef] [PubMed]

99. Warnock, G.L.; Dabbs, K.D.; Evans, M.G.; Cattral, M.S.; Kneteman, N.M.; Rajotte, R.V. Critical mass of islets that function after implantation in a large mammalian. Horm. Metab. Res. Suppl. 1990, 25, 156-161. [PubMed]

100. Scharp, D.W.; Marchetti, P.; Swanson, C.; Newton, M.; McCullough, C.S.; Olack, B. The effect of transplantation site and islet mass on long-term survival and metabolic and hormonal function of canine purified islet autografts. Cell Transplant. 1992, 1, 245-254. [CrossRef] [PubMed]

101. Motojima, K.; Kohara, N.; Maeda, J.; Yamaguchi, M.; Kanematsu, T. A comparison of endocrine and exocrine function after pancreatic fragment autotransplantation into splenic pulp, portal vein, and hepatic parenchyma. Transplantation 1992, 53, 527-532. [CrossRef] [PubMed]

102. Marchetti, P.; Olack, B.; Swanson, C.; Newton, M.; Scharp, D.W. Assessment of long-term (1 year) graft survival and metabolic and hormonal changes after intrasplenic canine pancreatic microfragment transplantation. Diabetes Metab. 1993, 19, 17-24.

103. Toledo-Pereyra, L.H.; Gordon, D.A.; MacKenzie, G.H. Application of cryopreservation techniques to islet cell allotransplantation. Cryobiology 1983, 20, 205-210. [CrossRef]

104. Sandler, S.; Kojima, Y.; Andersson, A. Cryopreservation of mouse pancreatic islets. Effects of fast cooling on islet B cell function and on the outcome of islet transplantation. Transplantation 1986, 42, 588-593. [CrossRef] [PubMed]

105. Heise, J.W.; Casanova, D.; Field, M.J.; Munn, S.R.; Najarian, J.S.; Sutherland, D.E. Cold storage preservation of pancreatic tissue prior to and after islet preparation in a dog autotransplantation model. J. Surg. Res. 1989, 47, 30-38. [CrossRef]

106. Casanova, D.; Heise, J.W.; Field, M.J.; Munn, S.R.; Sutherland, D.E. Successful transplantation of canine islets of Langerhans after 24 hours cold-storage. Diabetes Res. 1989, 10, 31-34. [PubMed]

107. Merrell, R.C.; Mahoney, M.E.; Basadonna, G.; Cobb, L.F.; Maeda, M. Failure of canine islet allografts and autografts with cyclosporine. Surgery 1985, 98, 324-329. [PubMed]

108. Basadonna, G.; Kakizaki, K.; Merrell, R.C. Effect of cyclosporine on established islet autografts. J. Surg. Res. 1986, 40, 450-454. [CrossRef]

109. Kneteman, N.M.; Alderson, D.; Scharp, D.W. Long-term normoglycemia in pancreatectomized dogs following pancreatic islet allotransplantation and cyclosporine immunosuppression. Transplantation 1987, 44, 595-599. [CrossRef] [PubMed]

110. Kneteman, N.M.; Marchetti, P.; Tordjman, K.; Bier, D.M.; Santiago, J.V.; Swanson, C.J.; Olack, B.J.; Scharp, D.W. Effects of cyclosporine on insulin secretion and insulin sensitivity in dogs with intrasplenic islet autotransplants. Surgery 1992, 111, 430-437. [PubMed]

111. Hesse, U.J.; Meyer, G.P.; Weyer, J.; Danis, J.; Pichlmaier, H. Islet isolation and autotransplantation in pigs. Zentralbl. Chir. 1994, 119, 653-660. [PubMed]

112. Gray, D.W. Islet isolation and transplantation techniques in the primate. Surg. Gynecol. Obstet. 1990, 170, 225-232. [PubMed]

113. Gray, D.W.; Warnock, G.L.; Sutton, R.; Peters, M.; McShane, P.; Morris, P.J. Successful autotransplantation of isolated islets of Langerhans in the cynomolgus monkey. Br. J. Surg. 1986, 73, 850-853. [CrossRef] [PubMed]

114. Sutton, R.; Gray, D.W.; Burnett, M.; McShane, P.; Turner, R.C.; Morris, P.J. Metabolic function of intraportal and intrasplenic islet autografts in cynomolgus monkeys. Diabetes 1989, 38 (Suppl. 1), 182-184. [CrossRef] [PubMed]

115. Du Toit, D.F.; Reece-Smith, H.; McShane, P.; Denton, T.; Morris, P.J. Effect of cyclosporin A on allotransplanted pancreatic fragments to the spleen of totally pancreatectomized dogs. Transplantation 1982, 33, 302-307. [CrossRef] [PubMed]

116. Janney, C.G.; Lacy, P.E.; Finke, E.H.; Davie, J.M. Prolongation of intrasplenic islet xenograft survival. Am. J. Pathol. 1982, 107, 1-5. [PubMed] 
117. Yakimets, W.J.; Lakey, J.R.; Yatscoff, R.W.; Katyal, D.; Ao, Z.; Finegood, D.T.; Rajotte, R.V.; Kneteman, N.M. Prolongation of canine pancreatic islet allograft survival with combined rapamycin and cyclosporine therapy at low doses. Rapamycin efficacy is blood level related. Transplantation 1993, 56, 1293-1298. [CrossRef] [PubMed]

118. Andersson, A. Reversal of hyperglycemia by intrasplenic transplantation of 4-week-cultured allogeneic mouse islets. Diabetes 1982, 31 (Suppl. 4), 55-59. [CrossRef] [PubMed]

119. Mehigan, D.G.; Zuidema, G.D.; Cameron, J.L. Pancreatic islet transplantation in dogs. Critical factors in technique. Am. J. Surg. 1981, 141, 208-212. [CrossRef]

120. Andersson, A.; Eriksson, U.; Petersson, B.; Reibring, L.; Swenne, I. Failure of successful intrasplenic transplantation of islets from lean mice to cure obese-hyperglycaemic mice, despite islet growth. Diabetologia 1981, 20, 237-241. [CrossRef] [PubMed]

121. Steffes, M.W.; Nielsen, O.; Dyrberg, T.; Baekkeskov, S.; Scott, J.; Lernmark, A. Islet transplantation in mice differing in the I and S subregions of the H-2 complex. Transplantation 1981, 31, 476-479. [CrossRef] [PubMed]

122. Warnock, G.L.; Rajotte, R.V.; Procyshyn, A.W. Normoglycemia after reflux of islet-containing pancreatic fragments into the splenic vascular bed in dogs. Diabetes 1983, 32, 452-459. [CrossRef] [PubMed]

123. Andersson, A. The influence of hyperglycaemia, hyperinsulinaemia and genetic background on the fate of intrasplenically implanted mouse islets. Diabetologia 1983, 25, 269-272. [CrossRef] [PubMed]

124. Kneteman, N.M.; Rajotte, R.V.; Procyshyn, A.W. Canine pancreatic fragment allotransplantation with cyclosporine A. J. Surg. Res. 1985, 39, 285-293. [CrossRef]

125. Hayek, A.; Lopez, A.D.; Beattie, G.M. Decrease in the number of neonatal islets required for successful transplantation by strict metabolic control of diabetic rats. Transplantation 1988, 45, 940-942. [CrossRef] [PubMed]

126. Ziegler, B.; Kohler, E.; Kloting, I.; Besch, W.; Ziegler, M. Survival of islet isografts despite cytotoxicity against pancreatic islets measured in vitro. Exp. Clin. Endocrinol. 1990, 95, 31-38. [CrossRef] [PubMed]

127. Korsgren, O.; Jansson, L.; Sandler, S.; Andersson, A. Hyperglycemia-induced B cell toxicity. The fate of pancreatic islets transplanted into diabetic mice is dependent on their genetic background. J. Clin. Investig. 1990, 86, 2161-2168. [CrossRef] [PubMed]

128. Eizirik, D.L.; Jansson, L.; Flodstrom, M.; Hellerstrom, C.; Andersson, A. Mechanisms of defective glucose-induced insulin release in human pancreatic islets transplanted to diabetic nude mice. J. Clin. Endocrinol. Metab. 1997, 82, 2660-2663. [CrossRef] [PubMed]

129. Stokes, R.A.; Simond, D.M.; Burns, H.; Patel, A.T.; O'Connell, P.J.; Gunton, J.E.; Hawthorne, W.J. Transplantation sites for porcine islets. Diabetologia 2017, 60, 1972-1976. [CrossRef] [PubMed]

130. Stokes, R.A.; Cheng, K.; Lalwani, A.; Swarbrick, M.M.; Thomas, H.E.; Loudovaris, T.; Kay, T.W.; Hawthorne, W.J.; O'Connell, P.J.; Gunton, J.E. Transplantation sites for human and murine islets. Diabetologia 2017, 60, 1961-1971. [CrossRef] [PubMed]

131. Gustavson, S.M.; Rajotte, R.V.; Hunkeler, D.; Lakey, J.R.; Edgerton, D.S.; Neal, D.W.; Snead, W.L.; Penaloza, A.R.; Cherrington, A.D. Islet auto-transplantation into an omental or splenic site results in a normal beta cell but abnormal alpha cell response to mild non-insulin-induced hypoglycemia. Am. J. Transplant. 2005, 5, 2368-2377. [CrossRef] [PubMed]

132. Cesta, M.F. Normal structure, function, and histology of the spleen. Toxicol. Pathol. 2006, 34, 455-465. [CrossRef] [PubMed]

133. Wang, D.; Gaba, R.C.; Jin, B.; Lewandowski, R.J.; Riaz, A.; Memon, K.; Ryu, R.K.; Sato, K.T.; Kulik, L.M.; Mulcahy, M.F.; et al. Perfusion reduction at transcatheter intraarterial perfusion MR imaging: A promising intraprocedural biomarker to predict transplant-free survival during chemoembolization of hepatocellular carcinoma. Radiology 2014, 272, 587-597. [CrossRef] [PubMed]

134. Lange, S.S.; Mitchell, D.L.; Vasquez, K.M. High mobility group protein B1 enhances DNA repair and chromatin modification after DNA damage. Proc. Natl. Acad. Sci. USA 2008, 105, 10320-10325. [CrossRef] [PubMed]

135. Bianchi, M.E.; Manfredi, A.A. High-mobility group box 1 (HMGB1) protein at the crossroads between innate and adaptive immunity. Immunol. Rev. 2007, 220, 35-46. [CrossRef] [PubMed]

136. Yanai, H.; Ban, T.; Wang, Z.; Choi, M.K.; Kawamura, T.; Negishi, H.; Nakasato, M.; Lu, Y.; Hangai, S.; Koshiba, R.; et al. HMGB proteins function as universal sentinels for nucleic-acid-mediated innate immune responses. Nature 2009, 462, 99-103. [CrossRef] [PubMed] 
137. Limana, F.; Germani, A.; Zacheo, A.; Kajstura, J.; Di Carlo, A.; Borsellino, G.; Leoni, O.; Palumbo, R.; Battistini, L.; Rastaldo, R.; et al. Exogenous high-mobility group box 1 protein induces myocardial regeneration after infarction via enhanced cardiac C-kit+ cell proliferation and differentiation. Circ. Res. 2005, 97, e73-e83. [CrossRef] [PubMed]

138. Chadburn, A. The spleen: Anatomy and anatomical function. Semin. Hematol. 2000, 37 (Suppl. 1), $13-21$. [CrossRef]

139. Tran, S.D.; Kodama, S.; Lodde, B.M.; Szalayova, I.; Key, S.; Khalili, S.; Faustman, D.L.; Mezey, E. Reversal of Sjogren's-like syndrome in non-obese diabetic mice. Ann. Rheum. Dis. 2007, 66, 812-814. [CrossRef] [PubMed]

140. Robertson, S.A.; Rowan-Hull, A.M.; Johnson, P.R. The spleen-a potential source of new islets for transplantation? J. Pediatr. Surg. 2008, 43, 274-278. [CrossRef] [PubMed]

141. Atkinson, M.A.; Leiter, E.H. The NOD mouse model of type 1 diabetes: As good as it gets? Nat. Med. 1999, 5, 601-604. [CrossRef] [PubMed]

142. Xu, J.; Wang, D.; Liu, D.; Fan, Z.; Zhang, H.; Liu, O.; Ding, G.; Gao, R.; Zhang, C.; Ding, Y.; et al. Allogeneic mesenchymal stem cell treatment alleviates experimental and clinical Sjogren syndrome. Blood 2012, 120, 3142-3151. [CrossRef] [PubMed]

143. Owens, B.M.; Hawley, T.S.; Spain, L.M.; Kerkel, K.A.; Hawley, R.G. TLX1/HOX11-mediated disruption of primary thymocyte differentiation prior to the CD4+CD8+ double-positive stage. Br. J. Haematol. 2006, 132, 216-229. [CrossRef] [PubMed]

144. Ferrando, A.A.; Neuberg, D.S.; Dodge, R.K.; Paietta, E.; Larson, R.A.; Wiernik, P.H.; Rowe, J.M.; Caligiuri, M.A.; Bloomfield, C.D.; Look, A.T. Prognostic importance of TLX1 (HOX11) oncogene expression in adults with T-cell acute lymphoblastic leukaemia. Lancet 2004, 363, 535-536. [CrossRef]

145. Raju, K.; Tang, S.; Dube, I.D.; Kamel-Reid, S.; Bryce, D.M.; Breitman, M.L. Characterization and developmental expression of Tlx-1, the murine homolog of HOX11. Mech. Dev. 1993, 44, 51-64. [CrossRef]

146. Dear, T.N.; Colledge, W.H.; Carlton, M.B.; Lavenir, I.; Larson, T.; Smith, A.J.; Warren, A.J.; Evans, M.J.; Sofroniew, M.V.; Rabbitts, T.H. The Hox11 gene is essential for cell survival during spleen development. Development 1995, 121, 2909-2915. [PubMed]

(C) 2018 by the authors. Licensee MDPI, Basel, Switzerland. This article is an open access article distributed under the terms and conditions of the Creative Commons Attribution (CC BY) license (http://creativecommons.org/licenses/by/4.0/). 